\title{
RECENT ADVANCES IN LAMELLARIN ALKALOIDS: ISOLATION, SYNTHESIS AND ACTIVITY
}

Daniel Pla, ${ }^{\mathrm{a}, \mathrm{b}}$ Fernando Albericio ${ }^{\mathrm{a}, \mathrm{b}, \mathrm{c}}$ and Mercedes Álvarez ${ }^{\mathrm{a}, \mathrm{b}, \mathrm{d}}$

a: Institute for Research in Biomedicine, Barcelona Science Park, University of

Barcelona, 08028-Barcelona, Spain;

b: CIBER-BBN Networking Centre on Bioengineering, Biomaterials and Nanomedicine, E-08028 Barcelona, Spain;

c: Department of Organic Chemistry, University of Barcelona, 08028-Barcelona, Spain;

d: Laboratory of Organic Chemistry, Faculty of Pharmacy, University of Barcelona,

08028-Barcelona, Spain

\begin{abstract}
Lamellarins are a large family of marine alkaloids with potential anticancer activity that have been isolated from diverse marine organisms, mainly ascidians and sponges. All lamellarins feature a 3,4diarylpyrrole system. Pentacyclic lamellarins, whose polyheterocyclic system has a pyrrole core, are the most active compounds. Some of these alkaloids are potently cytotoxic to various tumor cell lines. To date, Lam-D and Lam-H have been identified as lead compounds for the inhibition of topoisomerase I and HIV-1 integrase, respectively_nuclear enzymes which are over-expressed in deregulation disorders. Moreover, these compounds have been reported for their efficacy in treatment of multi-drug resistant (MDR) tumors cells without mediated drug efflux, as well as their immunomodulatory activity and selectivity towards melanoma cell lines. This article is an overview of recent literature on lamellarins, encompassing their isolation, recent synthetic strategies for their total synthesis, the preparation of their analogs, studies on their mechanisms of action, and their structure-activity relationships (SAR).
\end{abstract}

Key Words: Lamellarins, Marine Alkaloids, Nitrogen Heterocycles, Cytotoxic Agents, Topoisomerase I 


\section{Introduction:}

Lamellarins are a large family of marine alkaloids characterized by their unusual structures and important activities. From a structural perspective, two groups of lamellarins can be found. Members of the larger of the two groups possess a pentacyclic system of 6-oxobenzo[b]pyrano[3,4-b]pyrrolo[2,1-a] with a substituted phenyl ring at position 14. Pentacyclic lamellarins may be saturated (Table 1) or unsaturated (Table 2) between positions 8 and 9.

Table 1. Structure of reduced pentacyclic lamellarins

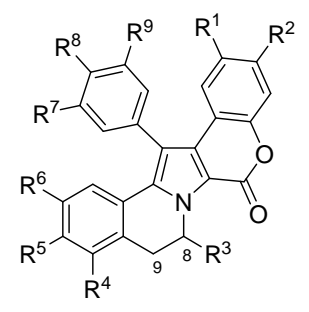

\begin{tabular}{|c|c|c|c|c|c|c|c|c|c|c|}
\hline Lamellarins & $\mathrm{R}^{1}$ & $\mathrm{R}^{2}$ & $\mathrm{R}^{3}$ & $\mathrm{R}^{4}$ & $\mathrm{R}^{5}$ & $\mathrm{R}^{6}$ & $\mathrm{R}^{7}$ & $\mathrm{R}^{8}$ & $\mathrm{R}^{9}$ & Ref \\
\hline Lam-A & $\mathrm{OMe}$ & $\mathrm{OH}$ & $\mathrm{OH}$ & $\mathrm{OMe}$ & $\mathrm{OMe}$ & $\mathrm{OMe}$ & $\mathrm{OMe}$ & $\mathrm{OH}$ & $\mathrm{H}$ & [1] \\
\hline Lam-C & $\mathrm{OMe}$ & $\mathrm{OH}$ & $\mathrm{H}$ & $\mathrm{OMe}$ & $\mathrm{OMe}$ & $\mathrm{OMe}$ & $\mathrm{OMe}$ & $\mathrm{OH}$ & $\mathrm{H}$ & [1] \\
\hline Lam-C sulf. & $\mathrm{OMe}$ & $\mathrm{OSO}_{3} \mathrm{Na}$ & $\mathrm{H}$ & $\mathrm{OMe}$ & $\mathrm{OMe}$ & $\mathrm{OMe}$ & $\mathrm{OMe}$ & $\mathrm{OH}$ & $\mathrm{H}$ & [2] \\
\hline Lam-E & $\mathrm{OMe}$ & $\mathrm{OH}$ & $\mathrm{H}$ & $\mathrm{OH}$ & $\mathrm{OMe}$ & $\mathrm{OMe}$ & $\mathrm{OH}$ & $\mathrm{OMe}$ & $\mathrm{H}$ & [3] \\
\hline Lam-F & $\mathrm{OMe}$ & $\mathrm{OH}$ & $\mathrm{H}$ & $\mathrm{OH}$ & $\mathrm{OMe}$ & $\mathrm{OMe}$ & $\mathrm{OMe}$ & $\mathrm{OMe}$ & $\mathrm{H}$ & [3] \\
\hline Lam-G & $\overline{\mathrm{OH}}$ & $\mathrm{OMe}$ & $\mathrm{H}$ & $\mathrm{H}$ & $\mathrm{OH}$ & $\mathrm{OMe}$ & $\mathrm{OH}$ & $\mathrm{OMe}$ & $\mathrm{H}$ & [3] \\
\hline Lam-G sulf. & $\mathrm{OH}$ & $\mathrm{OMe}$ & $\mathrm{H}$ & $\mathrm{OSO}_{3} \mathrm{Na}$ & $\mathrm{OH}$ & $\mathrm{OMe}$ & $\mathrm{OH}$ & $\mathrm{OMe}$ & $\mathrm{H}$ & [2] \\
\hline Lam-I & $\mathrm{OMe}$ & $\mathrm{OH}$ & $\mathrm{H}$ & $\mathrm{OMe}$ & $\mathrm{OMe}$ & $\mathrm{OMe}$ & OMe & $\mathrm{OMe}$ & $\mathrm{H}$ & [4] \\
\hline Lam-J & $\mathrm{OMe}$ & $\mathrm{OH}$ & $\mathrm{H}$ & $\mathrm{H}$ & $\mathrm{OH}$ & $\mathrm{OMe}$ & OMe & $\mathrm{OMe}$ & $\mathrm{H}$ & {$[4]$} \\
\hline Lam-K & $\mathrm{OMe}$ & $\mathrm{OH}$ & $\mathrm{H}$ & $\mathrm{OH}$ & $\mathrm{OMe}$ & $\mathrm{OMe}$ & $\mathrm{OMe}$ & $\mathrm{OH}$ & $\mathrm{H}$ & {$[4]$} \\
\hline Lam-L & $\mathrm{OMe}$ & $\mathrm{OH}$ & $\mathrm{H}$ & $\mathrm{H}$ & $\mathrm{OH}$ & $\mathrm{OMe}$ & $\mathrm{OH}$ & $\mathrm{OMe}$ & $\mathrm{H}$ & {$[4]$} \\
\hline L sulf. & $\mathrm{OMe}$ & $\mathrm{OSO}_{3} \mathrm{Na}$ & $\mathrm{H}$ & $\mathrm{H}$ & $\mathrm{OH}$ & $\mathrm{OMe}$ & $\mathrm{OH}$ & $\mathrm{OMe}$ & $\mathrm{H}$ & [2] \\
\hline Lam-S & $\mathrm{OH}$ & $\mathrm{OH}$ & $\mathrm{H}$ & $\mathrm{H}$ & $\mathrm{OH}$ & $\mathrm{OMe}$ & $\mathrm{OH}$ & $\mathrm{OH}$ & $\mathrm{H}$ & [2] \\
\hline Lam-T & $\mathrm{OMe}$ & $\mathrm{OH}$ & $\mathrm{H}$ & $\mathrm{OMe}$ & $\mathrm{OMe}$ & $\mathrm{OMe}$ & $\mathrm{OH}$ & $\mathrm{OMe}$ & $\mathrm{H}$ & [5] \\
\hline Lam-T sulf. & $\mathrm{OMe}$ & $\mathrm{OSO}_{3} \mathrm{Na}$ & $\mathrm{H}$ & $\mathrm{OMe}$ & $\mathrm{OMe}$ & $\mathrm{OMe}$ & $\mathrm{OMe}$ & $\mathrm{OH}$ & $\mathrm{H}$ & [5] \\
\hline Lam-U & $\mathrm{OMe}$ & $\mathrm{OH}$ & $\mathrm{H}$ & $\mathrm{H}$ & $\mathrm{OMe}$ & $\mathrm{OMe}$ & $\mathrm{OH}$ & $\mathrm{OMe}$ & $\mathrm{H}$ & [2] \\
\hline Lam-U sulf. & $\mathrm{OMe}$ & $\mathrm{OSO}_{3} \mathrm{Na}$ & $\mathrm{H}$ & $\mathrm{H}$ & $\mathrm{OMe}$ & $\mathrm{OMe}$ & $\mathrm{OH}$ & $\mathrm{OMe}$ & $\mathrm{H}$ & [5] \\
\hline Lam-V & $\mathrm{OMe}$ & $\mathrm{OH}$ & $\mathrm{OH}$ & $\mathrm{OMe}$ & $\mathrm{OMe}$ & $\mathrm{OMe}$ & $\mathrm{OH}$ & $\mathrm{OMe}$ & $\mathrm{H}$ & [5] \\
\hline Lam-V sulf. & OMe & $\mathrm{OSO}_{3} \mathrm{Na}$ & $\mathrm{OH}$ & $\mathrm{OMe}$ & $\mathrm{OMe}$ & $\mathrm{OMe}$ & $\mathrm{OH}$ & $\mathrm{OMe}$ & $\mathrm{H}$ & [5] \\
\hline Lam-Y & $\mathrm{OMe}$ & $\mathrm{OH}$ & $\mathrm{H}$ & $\mathrm{H}$ & $\mathrm{OMe}$ & $\mathrm{OH}$ & $\mathrm{OH}$ & $\mathrm{OMe}$ & $\mathrm{H}$ & [2] \\
\hline Lam-Y sulf. & $\mathrm{OMe}$ & $\mathrm{OSO}_{3} \mathrm{Na}$ & $\mathrm{H}$ & $\mathrm{H}$ & $\mathrm{OMe}$ & $\mathrm{OH}$ & $\mathrm{OH}$ & $\mathrm{OMe}$ & $\mathrm{H}$ & [5] \\
\hline Lam-Z & $\mathrm{OH}$ & $\mathrm{OMe}$ & $\mathrm{H}$ & $\mathrm{H}$ & $\mathrm{OH}$ & $\mathrm{OMe}$ & $\mathrm{OH}$ & $\mathrm{OH}$ & $\mathrm{H}$ & {$[2]$} \\
\hline Lam- $\beta$ & $\mathrm{OMe}$ & $\mathrm{OH}$ & $\mathrm{H}$ & $\mathrm{H}$ & $\mathrm{OH}$ & $\mathrm{OH}$ & $\mathrm{OH}$ & $\mathrm{OMe}$ & $\mathrm{H}$ & [6] \\
\hline
\end{tabular}




\begin{tabular}{|c|c|c|c|c|c|c|c|c|c|c|}
\hline Lam- $\gamma$ & $\mathrm{OMe}$ & $\mathrm{OH}$ & $\mathrm{H}$ & $\mathrm{OH}$ & $\mathrm{OMe}$ & $\mathrm{OMe}$ & $\mathrm{OH}$ & $\mathrm{OMe}$ & $\mathrm{OMe}$ & {$[7]$} \\
\hline Lam- $\chi$ triacetate & $\mathrm{OMe}$ & $\mathrm{OAc}$ & $\mathrm{H}$ & $\mathrm{H}$ & $\mathrm{OAc}$ & $\mathrm{OMe}$ & $\mathrm{OMe}$ & $\mathrm{OAc}$ & $\mathrm{H}$ & {$[8]$} \\
\hline Dihydro- Lam- $\eta$ & $\mathrm{OMe}$ & $\mathrm{OH}$ & $\mathrm{H}$ & $\mathrm{H}$ & $\mathrm{OMe}$ & $\mathrm{OMe}$ & $\mathrm{OMe}$ & $\mathrm{OMe}$ & $\mathrm{H}$ & {$[8]$} \\
\hline
\end{tabular}

Table 2. Structure of oxidized pentacyclic lamellarins

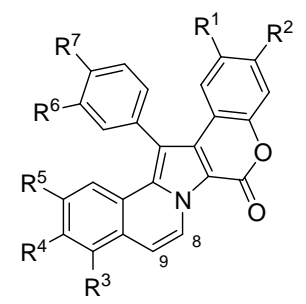

\begin{tabular}{|c|c|c|c|c|c|c|c|c|}
\hline Lamellarins & $\mathrm{R}^{1}$ & $\mathrm{R}^{2}$ & $\mathrm{R}^{3}$ & $\mathrm{R}^{4}$ & $\mathrm{R}^{5}$ & $\mathrm{R}^{6}$ & $\mathrm{R}^{7}$ & Ref \\
\hline Lam-B & $\mathrm{OMe}$ & $\mathrm{OH}$ & $\mathrm{OMe}$ & $\mathrm{OMe}$ & $\mathrm{OMe}$ & $\mathrm{OMe}$ & $\mathrm{OH}$ & [1] \\
\hline Lam-B sulf. & $\mathrm{OMe}$ & $\mathrm{OSO}_{3} \mathrm{Na}$ & $\mathrm{OMe}$ & $\mathrm{OMe}$ & $\mathrm{OMe}$ & $\mathrm{OMe}$ & $\mathrm{OH}$ & {$[2]$} \\
\hline Lam-D & $\mathrm{OMe}$ & $\mathrm{OH}$ & $\mathrm{H}$ & $\mathrm{OH}$ & $\mathrm{OMe}$ & $\mathrm{OMe}$ & $\mathrm{OH}$ & {$[1]$} \\
\hline Lam-H & $\mathrm{OH}$ & $\mathrm{OH}$ & $\mathrm{H}$ & $\mathrm{OH}$ & $\mathrm{OH}$ & $\mathrm{OH}$ & $\mathrm{OH}$ & {$[3]$} \\
\hline Lam-M & $\mathrm{OMe}$ & $\mathrm{OH}$ & $\mathrm{OH}$ & $\mathrm{OMe}$ & $\mathrm{OMe}$ & $\mathrm{OMe}$ & $\mathrm{OH}$ & [4] \\
\hline Lam-N & $\mathrm{OMe}$ & $\mathrm{OH}$ & $\mathrm{H}$ & $\mathrm{OH}$ & $\mathrm{OMe}$ & $\mathrm{OH}$ & $\mathrm{OMe}$ & [4] \\
\hline Lam-W & $\mathrm{OMe}$ & $\mathrm{OH}$ & $\mathrm{OMe}$ & $\mathrm{OMe}$ & $\mathrm{OMe}$ & $\mathrm{OH}$ & $\mathrm{OMe}$ & {$[5]$} \\
\hline Lam-X & $\mathrm{OMe}$ & $\mathrm{OH}$ & $\mathrm{OH}$ & $\mathrm{OMe}$ & $\mathrm{OMe}$ & $\mathrm{OH}$ & $\mathrm{OMe}$ & {$[2]$} \\
\hline Lam- $\alpha$ & $\mathrm{OMe}$ & $\mathrm{OH}$ & $\mathrm{H}$ & $\mathrm{OMe}$ & $\mathrm{OMe}$ & $\mathrm{OH}$ & $\mathrm{OMe}$ & [7] \\
\hline Lam- $\alpha$ sulf. & $\mathrm{OMe}$ & $\mathrm{OSO}_{3} \mathrm{Na}$ & $\mathrm{H}$ & $\mathrm{OMe}$ & $\mathrm{OMe}$ & $\mathrm{OH}$ & $\mathrm{OMe}$ & [9] \\
\hline Lam- $\zeta$ & $\mathrm{OMe}$ & $\mathrm{OH}$ & $\mathrm{OMe}$ & $\mathrm{OMe}$ & $\mathrm{OMe}$ & $\mathrm{OMe}$ & $\mathrm{OMe}$ & {$[8]$} \\
\hline Lam- $C$ & $\mathrm{OMe}$ & $\mathrm{OH}$ & $\mathrm{OH}$ & $\mathrm{OMe}$ & $\mathrm{OMe}$ & $\mathrm{OMe}$ & $\mathrm{OMe}$ & {$[7]$} \\
\hline Lam- $\eta$ & $\mathrm{OMe}$ & $\mathrm{OH}$ & $\mathrm{H}$ & $\mathrm{OMe}$ & $\mathrm{OMe}$ & $\mathrm{OMe}$ & $\mathrm{OMe}$ & [8] \\
\hline Lam- $\phi$ & $\mathrm{OMe}$ & OAc & $\mathrm{OMe}$ & $\mathrm{OMe}$ & OAc & $\mathrm{OMe}$ & OAc & {$[8]$} \\
\hline
\end{tabular}

Table 2. Structure of oxidized pentacyclic lamellarins

The second group of lamellarins, which are less structurally complex, are derivatives of methyl 3,4-bis( $p$ hydroxyphenyl)pyrrole-2-carboxylate, and which differ in their $N$-pyrrole substituent (Figure 1). Lamellarins $\mathrm{O}$ (Lam-O) and P (Lam-P) [10] contain a common $p$-methoxyacetophenone on their $N$-pyrrole, Lam-Q [11] has a un-substituted pyrrole, and Lam-R has an $N$-(p-hydroxyphenyl)pyrrole [11]. The bioactivities of these compounds are not significant. 

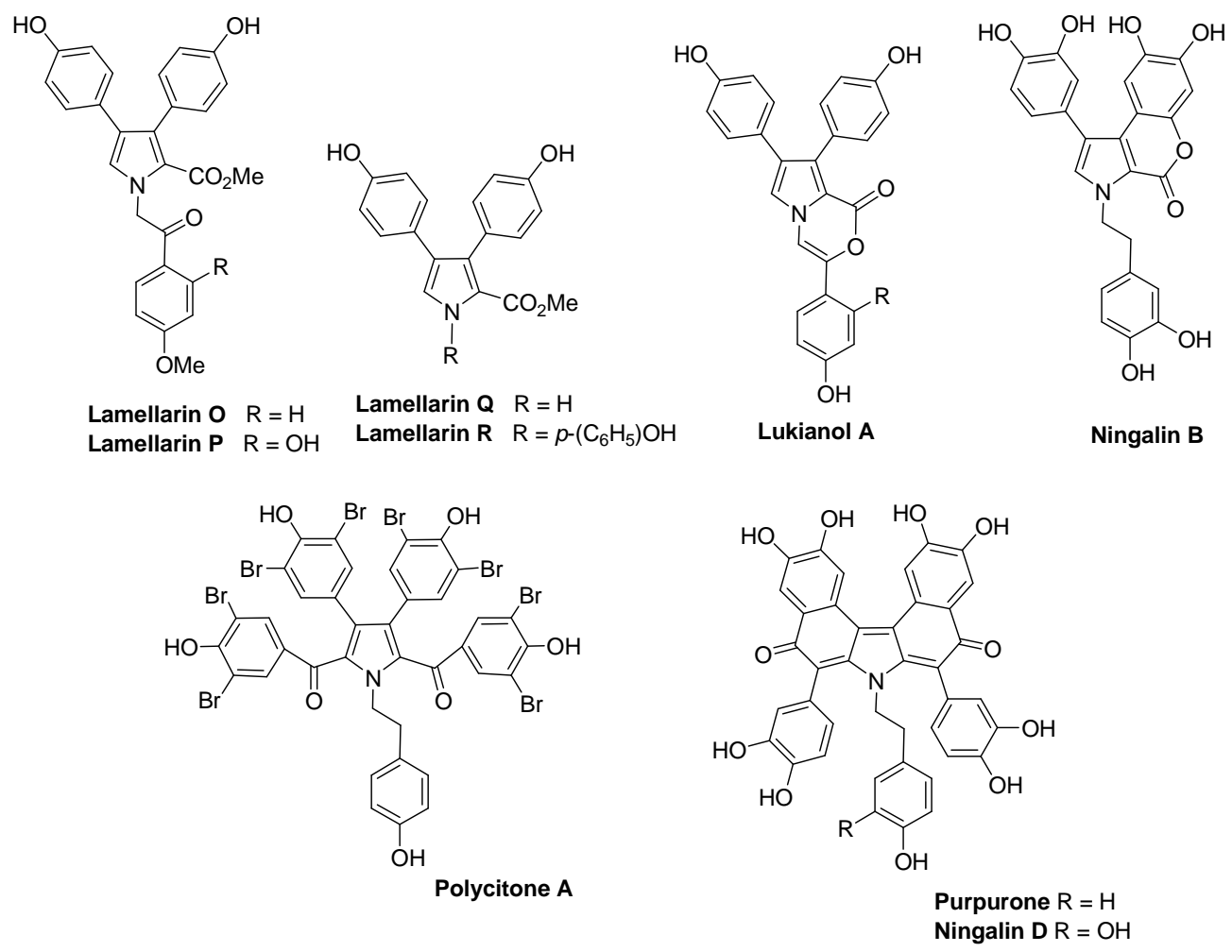

Fig. (1). Structures of lamellarins O-R, lukianol A, ningalins B and D, polycitone A, and purpurone

Lamellarins can be biosynthesized from three molecules of tyrosine or DOPA [4, 11], similarly to several related marine alkaloid families such as lukianols [12], ningalins [13], polycitones [14] and purpurone [15] (Figure 1).

Several reviews on lamellarins have recently been published [16]. Herein is covered work related to their isolation, synthesis and activity that was published between 2004 and December 2007.

\section{Isolation of lamellarins}

Lamellarins were initially isolated from a prosobranch mollusk of the genus Lamellaria [1] and subsequently found in various organisms, mostly ascidians, which are prey of the former. More than thirty lamellarins have been isolated to date, but only few show interesting bioactive properties [1-9]. Venkateswarlu et al. [7] recently isolated from the Indian red colonial ascidian Didemnum obscurum three new lamellarin alkaloids (Lam- $\gamma$, Lam- $\alpha$, and Lam- $\Theta$ ) plus eight known lamellarin alkaloids (Lam-M, Lam-K, Lam-K diacetate, Lam-K triacetate, Lam-U, Lam-I, Lam-C diacetate, and Lam-X triacetate). The same authors also described from the same ascidian four new lamellarin alkaloids (Lam- $\zeta$, Lam- $\eta$, Lam- $\phi$ and Lam- $\chi$ ) and seven known lamellarins (Lam-K, Lam-I, Lam-J, Lam-K triacetate, Lam-L triacetate, LamF and Lam-T diacetate) [8]. The structures of the lamellarins isolated by Venkateswarlu et al. [7, 8] were 
established using standard spectroscopic techniques, and the structure of Lam-K triacetate was confirmed by X-ray crystallographic analysis.

\section{Synthesis}

Lamellarins are rather complex structural targets. Several approaches to their synthesis can be found in the literature. These fall into two main synthetic categories: (a) pyrrole formation as the cornerstone of the synthesis; and (b) transformation of a pre-existing pyrrole derivative through cross-coupling reactions.

\section{a) Pyrrole ring formation}

A highly efficient synthesis of Lam-K and Lam-L was described by Ruchirawat et al. [17]. The pyrrole ring was constructed via Michael addition followed by a ring-closing reaction of benzyldihydroisoquinoline derivatives with ethoxycarbonyl- $\beta$-nitrostyrenes (Figure 2). Formation of the pyrrole ring produces the dihydropyrrolo[2,1-a]isoquinoline in which all the phenol groups were protected as benzyl-ethers. Deprotection by hydrogenolysis followed by base-mediated lactonization gave the natural products. The same methodology was used to prepare several natural saturated and unsaturated lamellarins, as well as various analogs [18].

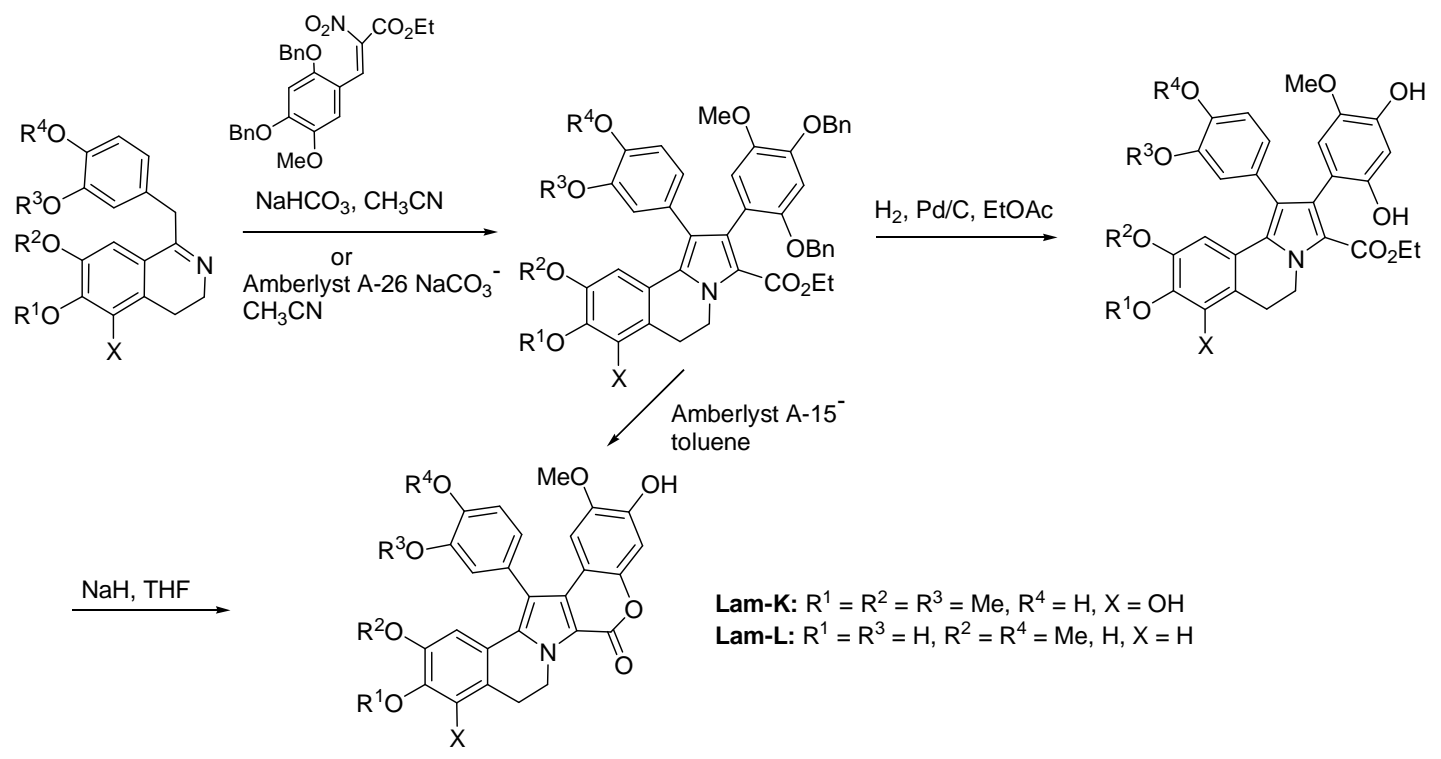

Fig. (2) . Synthesis of lamellarins K and L

The same authors reported an elegant preparation of the lamellarin skeleton using a slightly different pyrrole ring formation from benzyldihydroisoquinoline and a phenacyl bromide [19]. They used polymersupported reagents to simplify the work-up and obviate column chromatography. The pyrrole ring was constructed in one pot by quaternization of the isoquinoline followed by an aldol-type condensation. Subsequent intramolecular Friedel-Crafts transacylation, and finally, lactonization, afforded the lamellarin 
skeleton. As shown in Figure 3, polymer-supported reagents were used for the following steps: selective monobromination of ortho-substituted acetophenones (Amberlyst A-26 $\mathrm{Br}_{3}{ }^{-}$-form and PVPHP); basemediated pyrrole formation via condensation of benzyldihydroisoquinoline with either phenacyl bromide or $\alpha$-nitrocinnamate (Amberlyst A-26 $\mathrm{NaCO}_{3}{ }^{\mathrm{a}}$ form); and a novel acid-mediated lactone formation via either Friedel-Crafts transacylation and lactonization, or $O$-debenzylation and lactonization (Amberlyst-15).
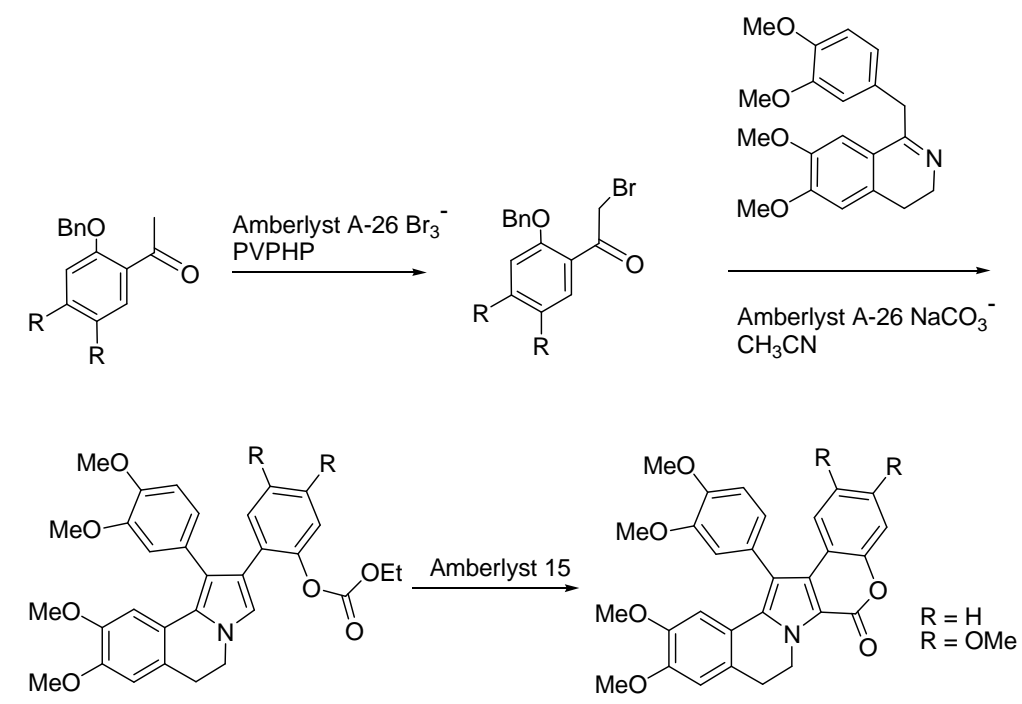

Fig. (3). Synthesis of the lamellarin skeleton with polymer-supported reagents

Several lamellarins and derivatives were obtained by solid-phase synthesis (SPS) on an appropriate solid support and under different cleavage conditions [20]. The lamellarin skeleton was synthesized on solid phase through formation of the pentacyclic system from an open chain dihydroisoquinolinium salt by an intramolecular [3+2] cycloaddition [21]. The use of different Lewis acids as cleavage-deprotection reagents in SPS has been exploited for introducing diversity to produce analogs for screening (Figure 4). 

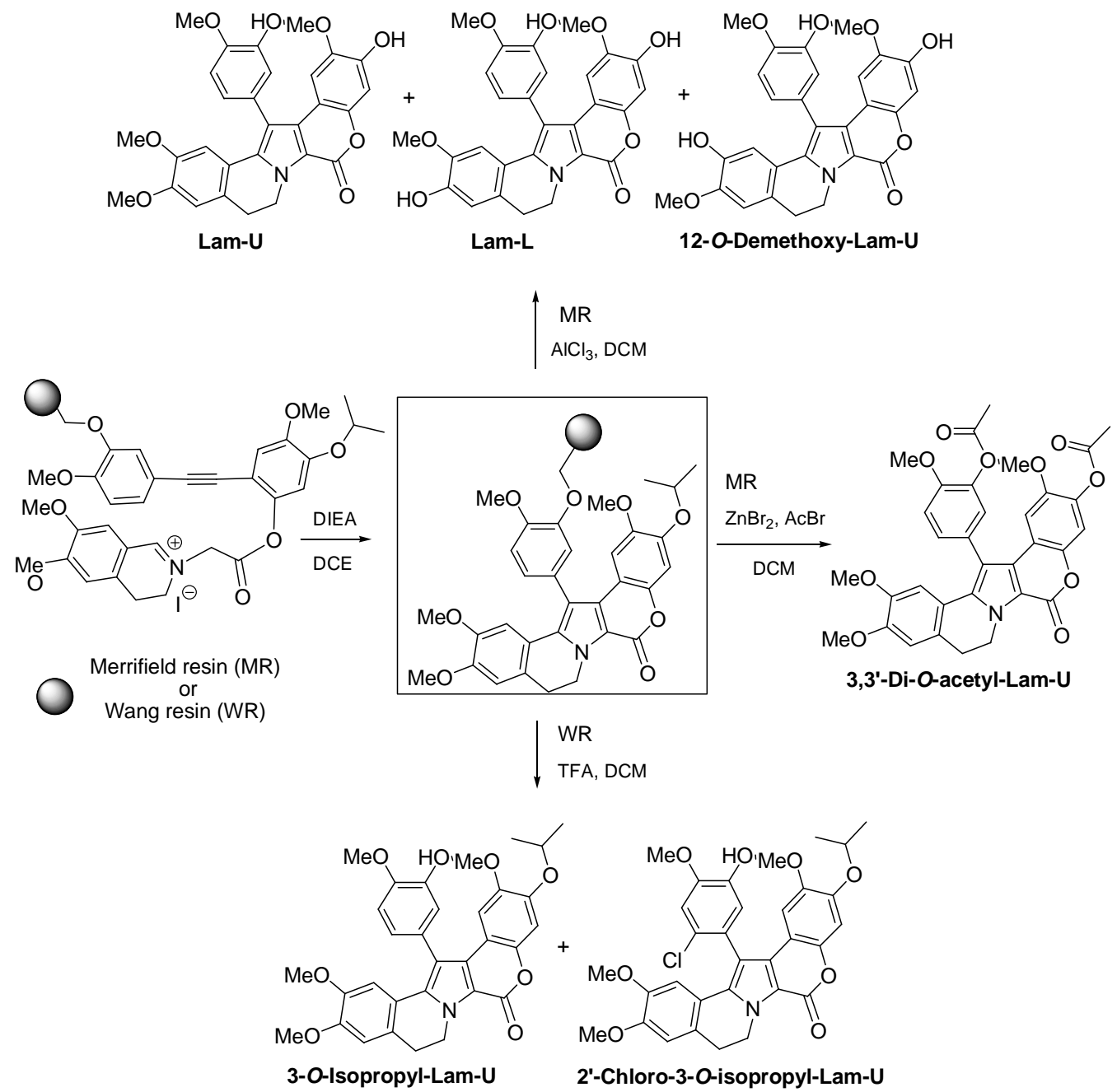

Fig. (4). Lewis acids for cleavage-deprotection in solid-phase synthesis

A biomimetic synthesis of lamellarin and lukianol skeleton was developed by Steglich et al. [22]. It is based on formation of 3,4-diarylpyrrole-2,5-dicarboxylic acid from aryl pyruvic acids and 2arylethylamines. The method has been used for the synthesis of ningalin B, Lam-G, Lam-K, lukianol A and a lukianol-lamellarin hybrid (Figure5). 

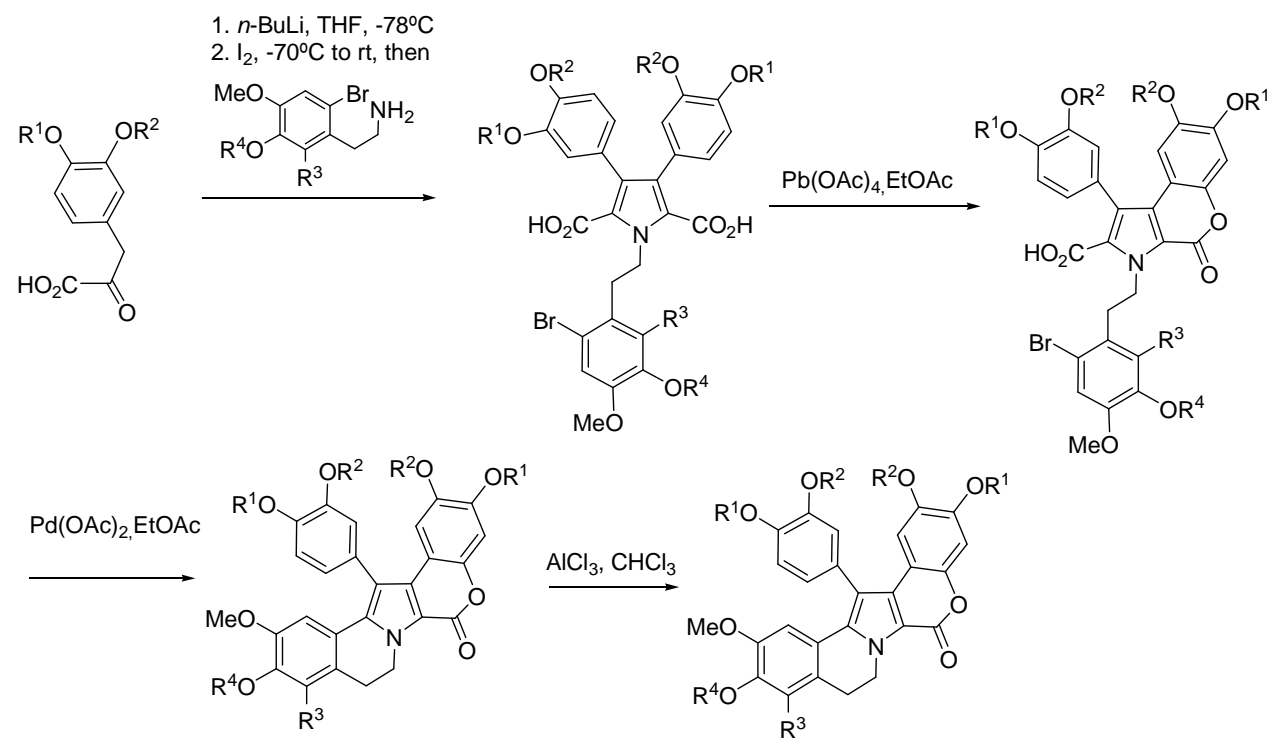

$$
\begin{aligned}
& \text { Lam-G: } R^{1}=M e, R^{2}=R^{3}=R^{4}=H \\
& \text { Lam-K: } R^{1}=H, R^{2}=R^{4}=M e, R^{3}=O H
\end{aligned}
$$

Fig. (5). Synthesis of lamellarins $\mathrm{G}$ and $\mathrm{K}$

Lam-Q dimethyl ether was obtained by Raney Ni reduction of 3,4-diarylpyrrole-2-carboxylates (1) [23], which were obtained by cyclization of $\alpha$-oxoketene- $N, S$-acetals in the presence of Vilsmeier reagent. LamQ dimethyl ether has been demonstrated to be a synthetic precursor of Lam-O dimethyl ether and lukianol A [24].
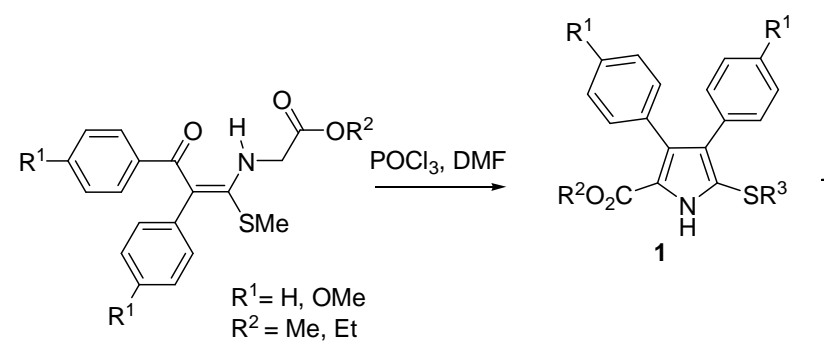

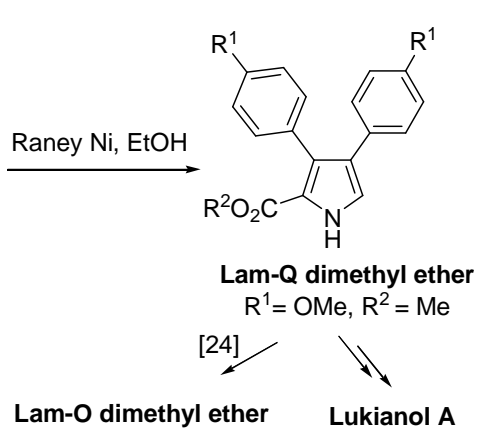

Fig. (6). Synthesis of lamellarin Q dimethyl ether

The total synthesis of Lam- $\alpha$ 20-sulfate [25] has been performed using a Hinsberg-type pyrrole synthesis and Suzuki-Miyaura cross-coupling as the key reactions. The synthesis featured an interesting combination of protecting groups for the phenols [26]. The pentacyclic system of lamellarins was obtained with two orthogonal protecting groups, isopropoxy (13-OiPr) and benzyloxy (20-OBn). The 20-sulfate analog was prepared by a sequence comprising debenzylation of Lam- $\alpha$ 20-OBn, formation of the 2,2,2trichloroethylsulfate of the resulting 20-OH, deprotection of $\mathrm{Lam}-\alpha$ 13-OiPr, and finally, reductive elimination of the 2,2,2-trichloroethyl sulfate protecting group (Figure 7). 

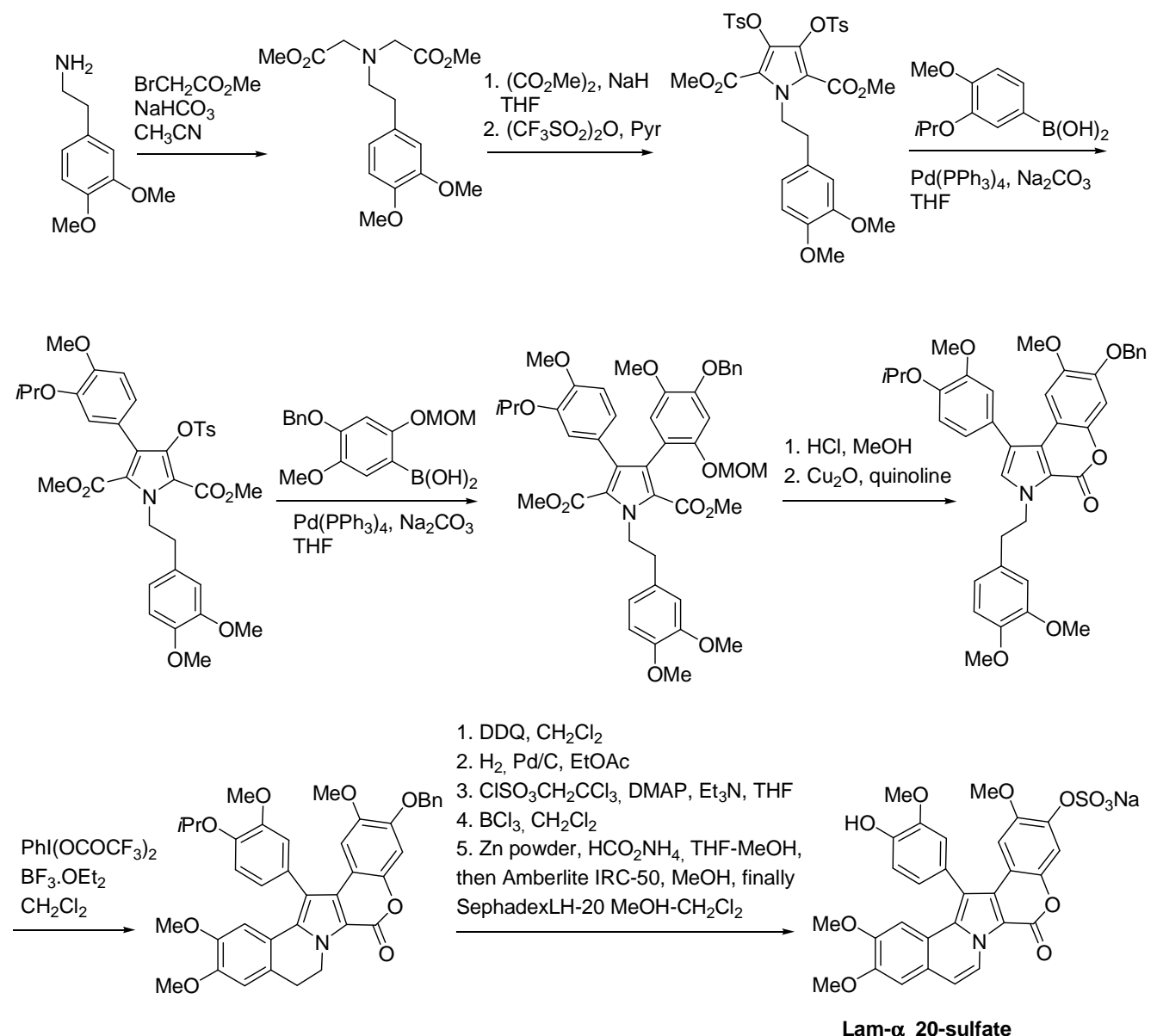

Fig. (7). Synthesis of lamellarin $\alpha 20$-sulfate

A similar procedure employing the appropiate boronic acids for the cross-coupling reaction has been used for the total synthesis of Lam-D, Lam-L, and Lam-N [27].

The 1,2-diaryl-substituted pyrrolo[2,1-a]isoquinoline skeleton of lamellarins has been obtained by a new route via 1,5-dipolar electrocyclization of azomethine ylides (Figure 8) [28]. The reagents comprised the stilbenic amides 2 available from the acids obtained by condensation of substituted benzaldehydes with phenylacetic acid. Cyclization of the amide 2 using the Bischler-Napieralski procedure afforded 3,4dihydroisoquinolines 3. Subsequent reaction of the isoquinolines with ethyl bromoacetate gave the quaternary salts, which upon treatment with triethylamine in dry ethanol afforded the pyrrole derivatives. Removal of the allylic protecting group with $\mathrm{Pd}-\mathrm{C}$ and $\mathrm{TsOH}$ resulted in simultaneous formation of the pentacyclic lamellarin skeleton and lactonization. This elegant method was not used for the preparation of a natural product; it was only applied to the construction of the lamellarin skeleton. 

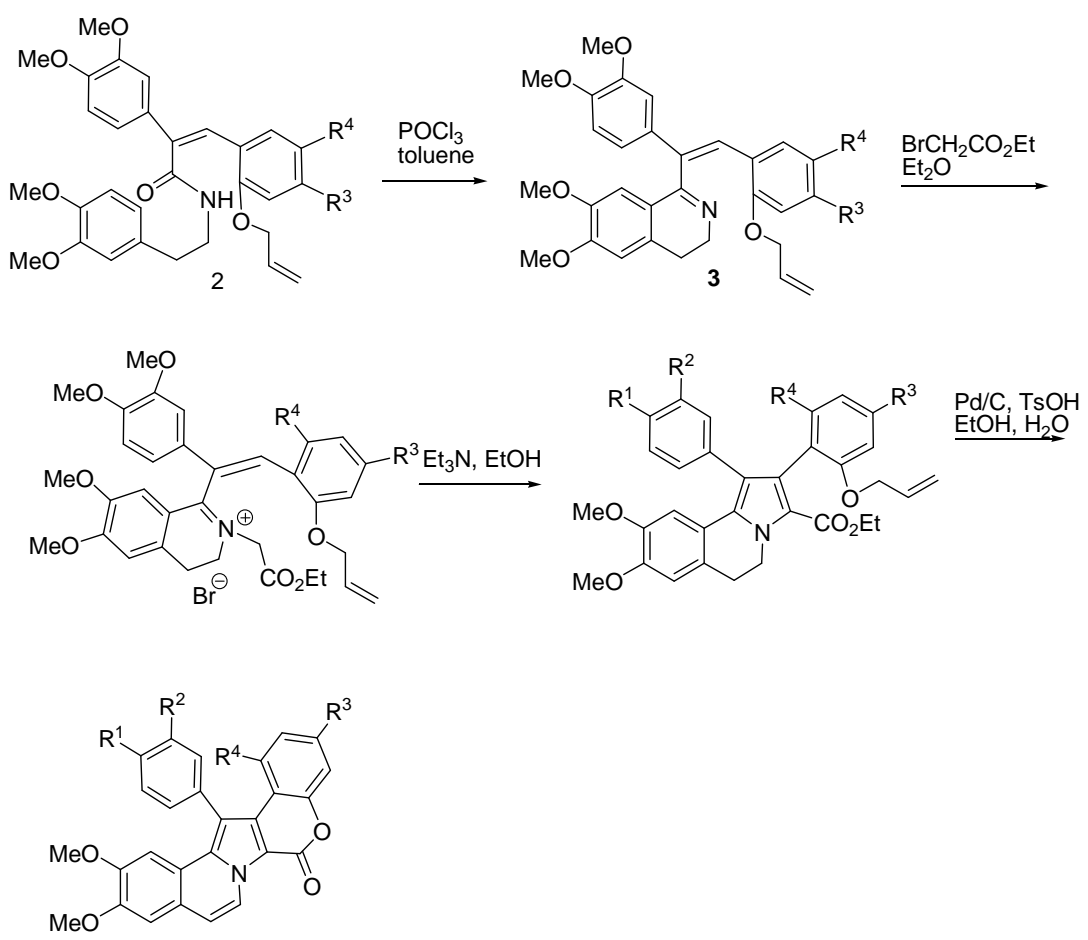

Fig. (8). Synthesis of the lamellarin skeleton by electrocyclization of azomethine ylides

A recently developed method for rapid access to the pyrroloisoquinoline core structures related to lamellarins is based on silver-catalyzed domino cycloisomerization-dipolar cycloaddition of alkynyl $\mathrm{N}$ benzylideneglycinate 4 and acetylene mono- or di-carboxylate (Figure 9). Reactions conducted at $60^{\circ} \mathrm{C}$ in toluene using 2,6-di-ter-butyl-4-methylpyridine (DTBMP) as base, and in the absence of oxidants, afforded optimal results (Figure 9). Several diversely substituted pyrroloisoquinolines were thus prepared [29].
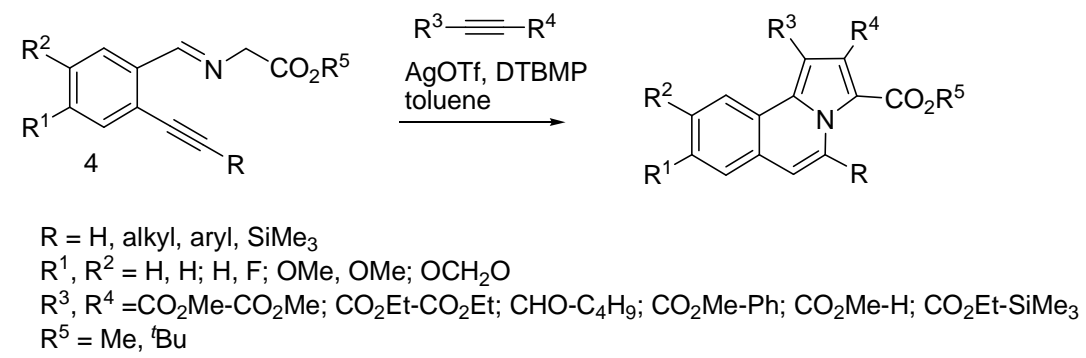

Fig. (9). Synthesis of pyrroloisoquinoline core structures of lamellarins

\section{b) Transformation of a pyrrole derivative through cross-coupling reactions}

Lam-Q and Lam-O have been synthesized on Merrifield resin with $N$-protected 3,4-dibromopyrrole-2carboxylate as scaffold (Figure 10) [30]. The process comprises incorporation of a substituted pyrrole ring 
onto a $p$-alkoxy iodo phenyl resin through a Negishi cross-coupling reaction, followed by Suzuki crosscoupling to introduce the second substituted phenyl ring, and finally, $N$-alkylation. A Lewis acid was used for the final cleavage. The beauty of this strategy is that diversity can be introduced at each step, including the final cleavage (by using the appropriate Lewis acid).
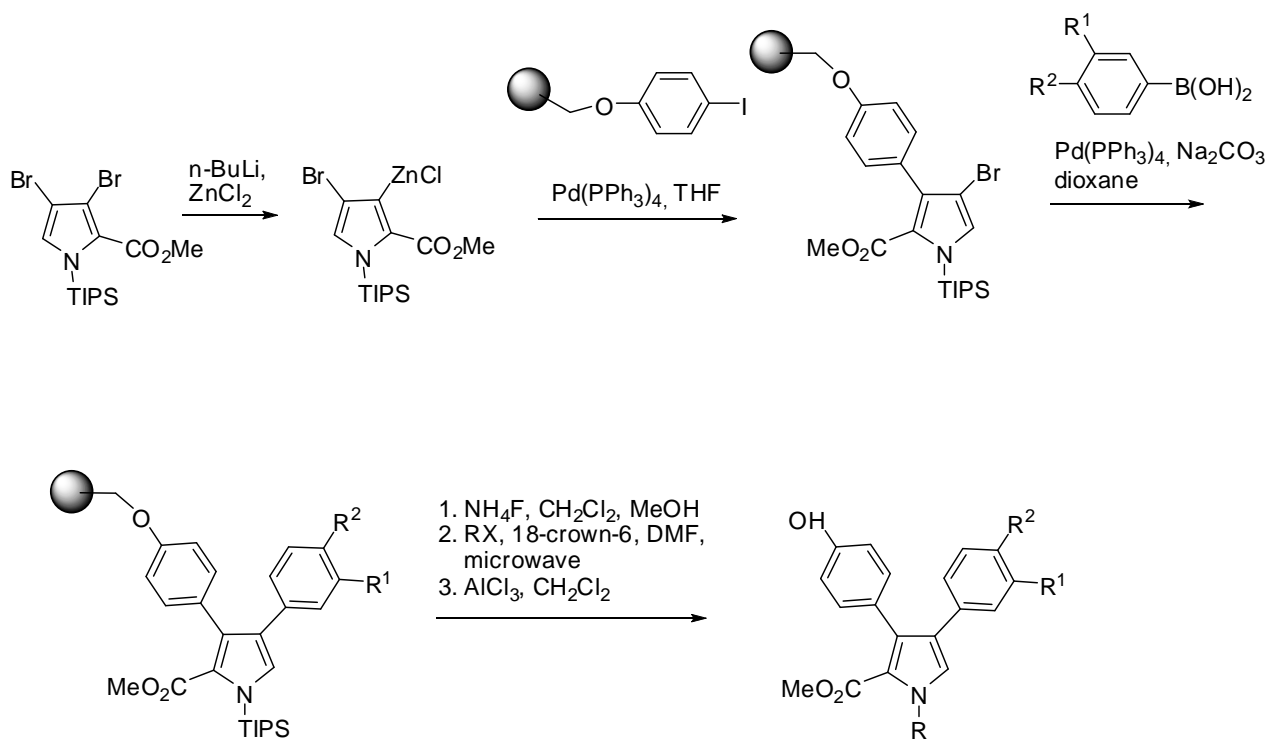

Lam-O: $\mathrm{R}=\mathrm{CH}_{2} \mathrm{COPh}, \mathrm{R}^{1}=\mathrm{H}, \mathrm{R}^{2}=\mathrm{OH}$

Lam-Q: $\mathrm{R}=\mathrm{R}^{1}=\mathrm{H}, \mathrm{R}^{2}=\mathrm{OH}$

Fig. (10). Solid phase synthesis of lamellarins $O$ and $Q$

Lam-G trimethyl ether has been obtained by three successive halogenation/cross couplings of a pyrrole-2carboxylate (Figure 11) [31]. Coupling of $N$-protected bromopyrrole 5 with boronic acid $\mathbf{6}$ gave the aryl pyrrole 7. Treatment of $\mathbf{7}$ with an equimolar amount of NBS led to selective halogenation at position C5. The second coupling with boronic acid $\mathbf{8}$ under Suzuki conditions gave the diarylpyrrole $\mathbf{9}$, which, owing to the quality of the hydroxyl function as a leaving group, readily underwent cyclization under basic conditions. 

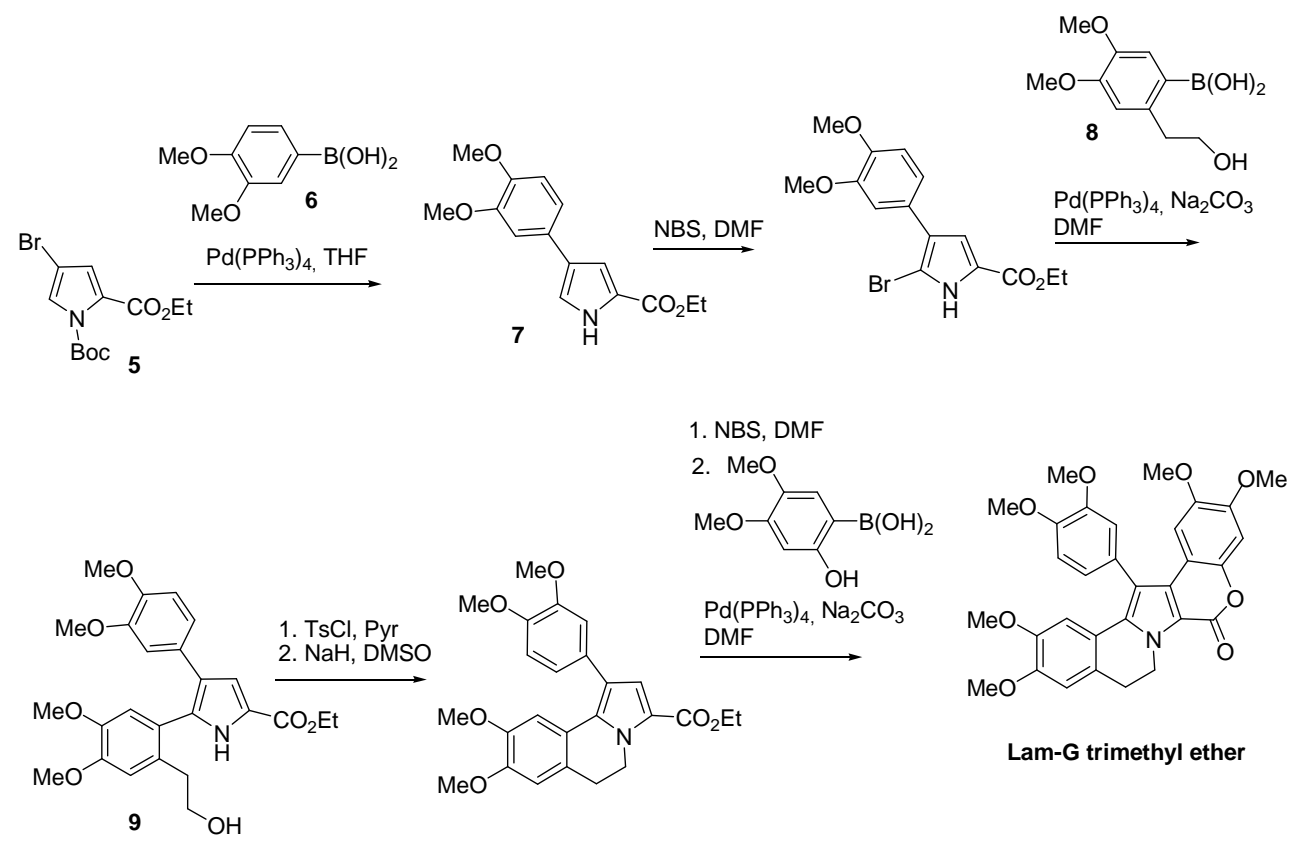

Fig. (11). Synthesis of lamellarin G trimethyl ether

A total synthesis of Lam-D has been developed starting from two sequential and regioselective bromination and cross-coupling reactions of the scaffold 10 [32], followed by oxidation, deprotection of the phenolgroups and lactonization (Figure 12) [33]. 

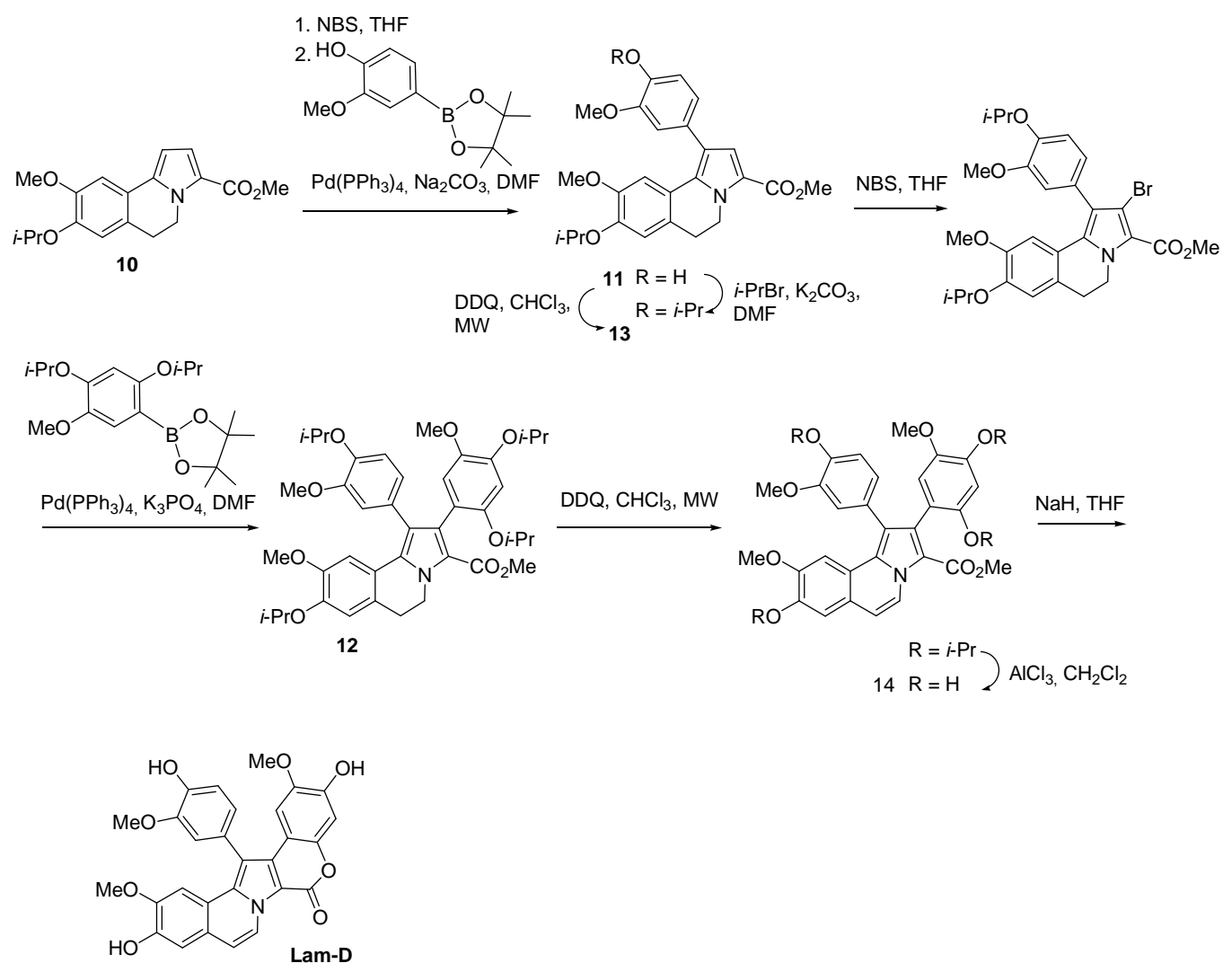

Fig. (12). Synthesis of lamellarin D

The aforementioned strategy has been employed to prepare numerous open chain analogs of lamellarins containing the mono- and bis-aryl scaffolds 11 and 12, respectively, and their corresponding oxidized derivatives 13 and 14 (see Table 5) [34]. Other C4-C5-bisarylpyrrole-2-carboxylate simplified analogs were synthesized by Banwell et al. [35].

Lam-Q dimethyl ether and Lam-O have been synthesized from C3-C4-bisaryl pyrroles obtained by regioselective halogenation and Suzuki-Miyaura reaction of a 2-trichloroacetylpyrrole (Figure 13) [36] .

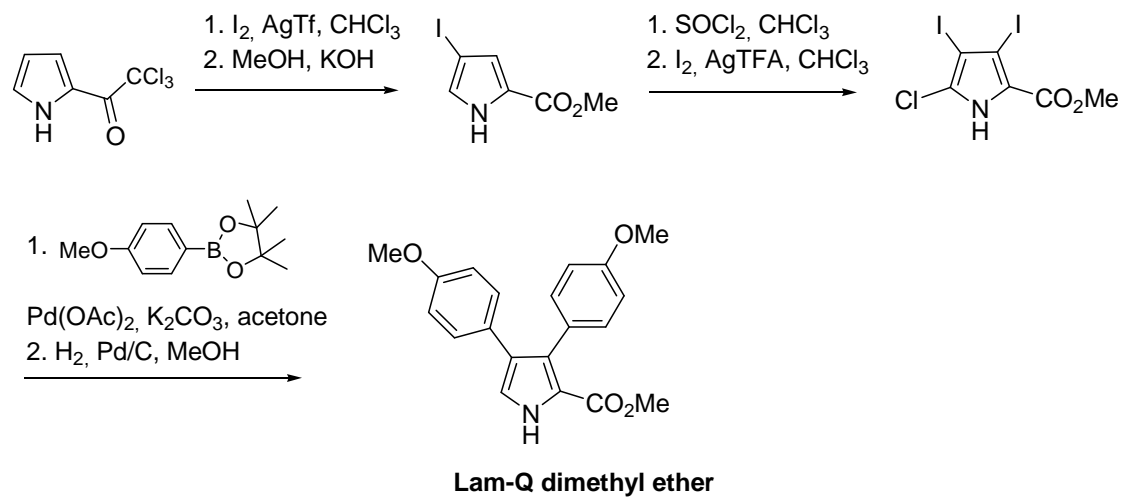

Fig. (13). Synthesis of lamellarin Q dimethyl ether 


\section{Activity and mechanism of action:}

Lamellarins and their derivatives are multi-drug resistance (MDR) reversal agents. As some of them are highly cytotoxic, they have been tested against various cancer cell lines. The results are summarized in Table 3.

Table 3. Cytotoxicity of isolated lamellarins to various culture cell lines

\begin{tabular}{|c|c|c|c|}
\hline Isolated Compound & Culture Cell Line ${ }^{a}$ & $\mathrm{IC}_{50}(\underline{\mathrm{M}})^{\mathrm{b}}$ & Ref \\
\hline \multirow[t]{10}{*}{ Lam-D } & $\mathrm{HeLa}$ & $10.510^{-9}$ & [39] \\
\hline & CEM & $510^{-9}$ & \multirow[t]{2}{*}{ [37] } \\
\hline & $\mathrm{CEM} / \mathrm{C} 2$ & $7.210^{-7}$ & \\
\hline & DU145 & $10.910^{-9 c}$ & [8] \\
\hline & MDA-MB-231 & $2.510^{-7 \mathrm{c}}$ & \multirow{3}{*}{ [34] } \\
\hline & A549 & $210^{-7 \mathrm{c}}$ & \\
\hline & HT29 & $5.110^{-6 c}$ & \\
\hline & $\mathrm{XC}$ & $1.2410^{-8}$ & \multirow{3}{*}{ [39] } \\
\hline & Vero Cells & $1.0510^{-8}$ & \\
\hline & MDCK & $2.2510^{-8}$ & \\
\hline Lam-F & COLO205 & $910^{-9}$ & [8] \\
\hline Lam-H & HeLa & $>10^{-6}$ & [39] \\
\hline \multirow[t]{3}{*}{ Lam-H hexaacetate } & HeLa & $1.1510^{-5}$ & [39] \\
\hline & CEM & $1.9510^{-6}$ & \multirow{2}{*}{ [37] } \\
\hline & CEM/C2 & $6.9310^{-6}$ & \\
\hline Lam-L triacetate & COLO205 & $0.2510^{-9}$ & [8] \\
\hline Lam-N & HeLa & $510^{-6}$ & [9] \\
\hline Lam-T & $\mathrm{HeLa}$ & $2.710^{-5 d}$ & [9] \\
\hline Lam-U sulf & $\mathrm{HeLa}$ & $1.410^{-4 \mathrm{~d}}$ & [9] \\
\hline Lam-V sulf & $\mathrm{HeLa}$ & $1.310^{-4 d}$ & [9] \\
\hline Lam-W & HeLa & $2.810^{-4 d}$ & [9] \\
\hline Lam- $\alpha$ & $\mathrm{HeLa}$ & $5.110^{-6 \mathrm{~d}}$ & [49] \\
\hline Lam- $\alpha$ sulf & HeLa & $2.7410^{-4 d}$ & [9] \\
\hline Lam- $\zeta$ & COLO205 & $5.610^{-9}$ & [8] \\
\hline Lam- $\chi$ & DU145 & $2.9910^{-6 c}$ & [8] \\
\hline Lam- $\chi$ triacetate & COLO205 & $0.210^{-9}$ & [8] \\
\hline \multirow[t]{4}{*}{ Lam- $\eta$} & $\mathrm{HeLa}$ & $2.510^{-6}$ & [39] \\
\hline & CEM & $3.0310^{-6}$ & \multirow{2}{*}{ [37] } \\
\hline & CEM/C2 & $5.5510^{-6}$ & \\
\hline & COLO205 & $1.7810^{-7}$ & [8] \\
\hline Lam-dihydro $\eta$ & COLO205 & $510^{-8}$ & [8] \\
\hline Lam- $\phi$ & COLO205 & $5.610^{-8}$ & {$[8]$} \\
\hline
\end{tabular}

a: cervical cancer cells (HeLa); human leukemic lymphoid cells (CEM); human leukemia cells resistant to camptothecin (CEM/C2); human prostate carcinoma cells (DU145); Rous sarcoma virus transformed rat cell line (XC); monkey kidney epithelial cells (Vero cells); Madin-Darby canine kidney cells (MDCK); colon cancer cells (COLO205); human breast adenocarcinoma cancer cells (MDA-MB-231); human colon cancer cells (HT29); human lung cancer cells (A549); b: IC: inhibitory concentration (in most cases the values not comparable, because the assays were performed in different conditions); c: GI: growth inhibition; d) LD: lethal dose 
Lam-D, Lam-K and Lam-M are among the most cytotoxic molecules in the series. The best studied member is Lam-D, which is highly cytotoxic to a wide range of tumor cell lines, particularly human prostate cancer cells [8] and leukemia cells [37]. Several molecular targets have been described for Lam-D and other lamellarins.

\section{Molecular structure-activity determinants}

Lamellarins with a C8-C9 double bond are generally more cytotoxic than their corresponding saturated analogs. This is very clear in the case of Lam-D, which is considerably more cytotoxic than its synthetic saturated analog, Lam-501 (Figure 14), which has no effect on topoisomerase I. As such, Bailly et al. postulated that the planarity of the pentacyclic structure is important for cytotoxicity [38].

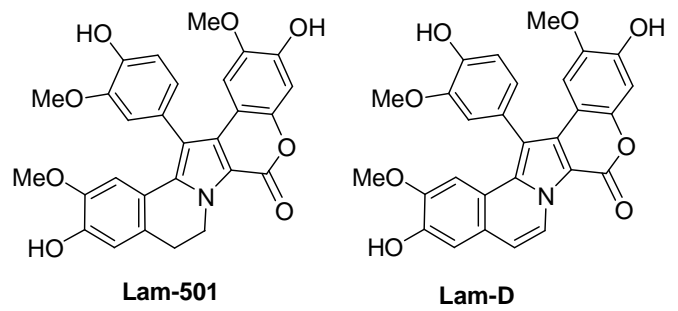

Fig. (14). The structures of lamellarin 501 and lamellarin D

Ishibashi et al. synthesized several derivatives of Lam-D [39], then evaluated the compounds for cytotoxicity against a HeLa cell line to determine the SAR. Their results are summarized in Table 4. Most of the derivatives with hydroxyl groups at both the $C-3$ and $C-11$ positions $(15 \mathbf{a}, 15 \mathbf{c}, 15 f$ and $15 \mathrm{~g})$ showed quite high activity, with $\mathrm{IC}_{50}$ values of $10.5-70.0 \mathrm{nM}$. The low toxicity of $\mathbf{1 5 b}$ might be partly due to its low solubility in the assay medium. The hydroxyl substituent at C-3 appears to be a prerequisite for activity, since the activity of $\mathbf{1 5 d}\left(\mathrm{IC}_{50}, 0.85 \mu \mathrm{M}\right)$, which lacks the hydroxyl group, was markedly lower than that of 15a $\left(\mathrm{IC}_{50}, 10.510^{-3} \mu \mathrm{M}\right)$. The importance of the 3-hydroxyl group for bioactivity is also apparent when comparing the activity of $15 \mathrm{e}\left(\mathrm{IC}_{50} 2.5 \mu \mathrm{M}\right)$ with those of $\mathbf{1 5 k}\left(\mathrm{IC}_{50}, 5.7 \mu \mathrm{M}\right)$ and $\mathbf{1 5 l}\left(\mathrm{IC}_{50}>100 \mu \mathrm{M}\right)$. The hydroxyl group at C-11 might also be important for activity, since methylation of both hydroxyl groups at C-11 and C-4' of 15a and 15e leads to much lower activity. In contrast, 15g, which has the 11-hydroxy group but lacks the 4'-hydroxyl group of $\mathbf{1 5 a}$, still maintains high activity. The presence of a hydroxyl group at C-4', and methoxy groups at C-3' and C-2, does not appear to affect activity, since the 4'dehydroxy, 3'-demethoxy, and 2-demethoxy derivatives (15g, 15f, and 15c, respectively) displayed slightly lower activity than the parent compound. In conclusion, this study provided basic SAR on Lam-D: hydroxyl groups at the C-3 and C-11 positions of $\mathbf{1 5 a}$ appear to be essential for cytotoxicity.

Table 4. Cytotoxic activity of lamellarin derivatives 15a-l on HeLa Cells [39] 


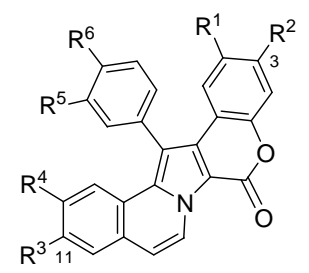

\begin{tabular}{|c|c|c|c|c|c|c|c|}
\hline Compound & $\mathbf{R}^{\mathbf{1}}$ & $\mathbf{R}^{\mathbf{2}}$ & $\mathbf{R}^{\mathbf{3}}$ & $\mathbf{R}^{\mathbf{4}}$ & $\mathbf{R}^{\mathbf{5}}$ & $\mathbf{R}^{\mathbf{6}}$ & $\mathbf{I C}_{\mathbf{5 0}}(\boldsymbol{\mu} \mathbf{M})$ \\
\hline $\mathbf{1 5 a}$ & $\mathrm{OMe}$ & $\mathrm{OH}$ & $\mathrm{OH}$ & $\mathrm{OMe}$ & $\mathrm{OMe}$ & $\mathrm{OH}$ & $10.510^{-3}$ \\
\hline $\mathbf{1 5 b}$ & $\mathrm{OH}$ & $\mathrm{OH}$ & $\mathrm{OH}$ & $\mathrm{OH}$ & $\mathrm{OH}$ & $\mathrm{OH}$ & $>100$ \\
\hline $\mathbf{1 5 c}$ & $\mathrm{H}$ & $\mathrm{OH}$ & $\mathrm{OH}$ & $\mathrm{OMe}$ & $\mathrm{OMe}$ & $\mathrm{OH}$ & $39.510^{-3}$ \\
\hline $\mathbf{1 5 d}$ & $\mathrm{OMe}$ & $\mathrm{H}$ & $\mathrm{OH}$ & $\mathrm{OMe}$ & $\mathrm{OMe}$ & $\mathrm{OH}$ & 0.85 \\
\hline $\mathbf{1 5} \mathbf{n}$ & $\mathrm{OMe}$ & $\mathrm{OH}$ & $\mathrm{OMe}$ & $\mathrm{OMe}$ & $\mathrm{OMe}$ & $\mathrm{OMe}$ & 2.5 \\
\hline $\mathbf{1 5 f}$ & $\mathrm{OMe}$ & $\mathrm{OH}$ & $\mathrm{OH}$ & $\mathrm{OMe}$ & $\mathrm{H}$ & $\mathrm{OH}$ & $38.010^{-3}$ \\
\hline $\mathbf{1 5 g}$ & $\mathrm{OMe}$ & $\mathrm{OH}$ & $\mathrm{OH}$ & $\mathrm{OMe}$ & $\mathrm{OMe}$ & $\mathrm{H}$ & $70.010^{-3}$ \\
\hline $\mathbf{1 5 h}$ & $\mathrm{H}$ & $\mathrm{H}$ & $\mathrm{OH}$ & $\mathrm{OMe}$ & $\mathrm{OMe}$ & $\mathrm{OH}$ & 4.0 \\
\hline $\mathbf{1 5 i}$ & $\mathrm{H}$ & $\mathrm{H}$ & $\mathrm{OH}$ & $\mathrm{OH}$ & $\mathrm{OH}$ & $\mathrm{OH}$ & 1.1 \\
\hline $\mathbf{1 5 j}$ & $\mathrm{OAc}$ & $\mathrm{OAc}$ & $\mathrm{OAc}$ & $\mathrm{OAc}$ & $\mathrm{OAc}$ & $\mathrm{OAc}$ & 11.0 \\
\hline $\mathbf{1 5} \mathbf{1 5}$ & $\mathrm{H}$ & $\mathrm{H}$ & $\mathrm{OMe}$ & $\mathrm{OMe}$ & $\mathrm{OMe}$ & $\mathrm{OMe}$ & 5.7 \\
\hline $\mathbf{1 5}$ & $-\mathrm{OCH}$ & $\mathrm{O}-$ & $\mathrm{OMe}$ & $\mathrm{OMe}$ & $\mathrm{OMe}$ & $\mathrm{OMe}$ & $>100$ \\
\hline
\end{tabular}

These results agree with those of a molecular dynamics study performed by Iwao et al. [37] to establish molecular interactions for the complex of Lam-D and the enzyme topoisomerase I. These researchers proposed that the guanidinium group of $\mathrm{Arg}^{364}$ maintains a close relationship with the lactone ring of the molecule. Moreover, they observed that direct hydrogen bonding interactions between the 3-OH oxygen and the $\mathrm{Glu}^{356}$ carboxylate oxygen, and between the 11-OH oxygen and the side chain amide nitrogen of $\mathrm{Asn}^{722}$, were maintained throughout the entire simulation.

A library of open lactone analogs of Lam-D [34] was recently synthesized (Table 5). The 45 members of the library all feature a methyl 8-hydroxy-9-methoxypyrrolo[2,1-a]isoquinoline-3-carboxylate scaffold, which differs from Lam-D primarly in that it lacks a lactone ring. The absence of the pyranone ring affords flexibility to the derivatives, and more importantly, greater solubility. Two series of compounds were prepared: derivatives of the 1-aryl-scaffold and of the 1,2-diaryl-scaffold. Members of both series feature either a single or double bond between $\mathrm{C} 5$ and $\mathrm{C} 6$ (which correspond to the $\mathrm{C} 8$ and $\mathrm{C} 9$ in lamellarins). The compounds from each series differ in their respective numbers and positions of the $\mathrm{OH} / \mathrm{OMe}$ substituents on the aryl rings, and in the presence of functional groups such as $\mathrm{NO}_{2}, \mathrm{NMe}_{2}, \mathrm{OCF}_{3}$ and heterocycles instead of aryl rings. All the compounds were tested for cytotoxicity against a panel of three human tumor cell lines: A-549 lung carcinoma, HT-29 colon carcinoma and MDA-MB-231 breast adenocarcinoma. The most active compounds are shown in Table 5. 
Table 5. Cytotoxicity $\left(\mathrm{GI}_{50} \mu \mathrm{M}\right)$ of open-lactone lamellarin analogs to various cancer cell lines [34]
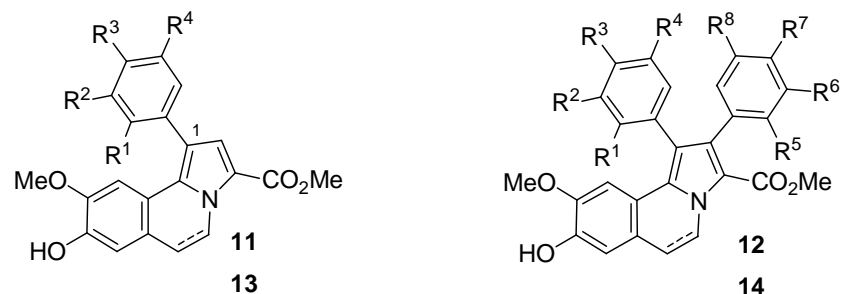

\begin{tabular}{|c|c|c|c|c|c|c|c|c|c|c|c|c|}
\hline Cmpd. & $\mathbf{B d}^{\mathbf{a}}$ & $\mathbf{R}^{1}$ & $\mathbf{R}^{2}$ & $\mathbf{R}^{3}$ & $\mathbf{R}^{4}$ & $\mathbf{R}^{5}$ & $\mathbf{R}^{6}$ & $\mathbf{R}^{7}$ & $\mathbf{R}^{8}$ & $A-549^{b}$ & HT-29 ${ }^{c}$ & $\begin{array}{l}\text { MDA- } \\
\text { MB- } \\
\text { 231 }^{\text {d }}\end{array}$ \\
\hline \multicolumn{10}{|c|}{ Lam-D } & 0.20 & 5.1 & 0.25 \\
\hline 11a & $\mathrm{S}$ & $\mathrm{H}$ & $\mathrm{OMe}$ & $\mathrm{OH}$ & $\mathrm{H}$ & -- & -- & -- & -- & 14.2 & 18.0 & 22.3 \\
\hline $11 \mathrm{~b}$ & $\mathrm{~S}$ & $\mathrm{OMe}$ & $\mathrm{H}$ & $\mathrm{H}$ & $\mathrm{OMe}$ & -- & -- & -- & -- & n.a. & n.a. & 12.7 \\
\hline $12 \mathbf{a}$ & $\mathrm{S}$ & $\mathrm{H}$ & $\mathrm{OMe}$ & $\mathrm{OH}$ & $\mathrm{H}$ & $\mathrm{H}$ & $\mathrm{OMe}$ & $\mathrm{OH}$ & $\mathrm{H}$ & 14.3 & n.a. & 8.5 \\
\hline $12 \mathrm{~b}$ & $\mathrm{~S}$ & $\mathrm{H}$ & $\mathrm{OMe}$ & $\mathrm{OMe}$ & $\mathrm{H}$ & $\mathrm{H}$ & $\mathrm{OMe}$ & $\mathrm{OMe}$ & $\mathrm{H}$ & 11.2 & n.a. & 7.7 \\
\hline $12 \mathrm{c}$ & $\mathrm{S}$ & $\mathrm{H}$ & $\mathrm{H}$ & $\mathrm{OMe}$ & $\mathrm{H}$ & $\mathrm{H}$ & $\mathrm{H}$ & $\mathrm{OMe}$ & $\mathrm{H}$ & 9.2 & 10.3 & 14.4 \\
\hline 12d & $\mathrm{S}$ & $\mathrm{H}$ & $\mathrm{H}$ & $\mathrm{NMe}_{2}$ & $\mathrm{H}$ & $\mathrm{H}$ & $\mathrm{H}$ & $\mathrm{NMe}_{2}$ & $\mathrm{H}$ & n.a. & n.a. & 13.7 \\
\hline $12 \mathrm{e}$ & $\mathrm{S}$ & $\mathrm{H}$ & $\mathrm{NO}_{2}$ & $\mathrm{H}$ & $\mathrm{H}$ & $\mathrm{H}$ & $\mathrm{NO}_{2}$ & $\mathrm{H}$ & $\mathrm{H}$ & 18.0 & 11.3 & 10.1 \\
\hline $12 \mathrm{f}$ & $\mathrm{S}$ & $\mathrm{H}$ & $\mathrm{OMe}$ & $\mathrm{OH}$ & $\mathrm{H}$ & $\mathrm{OH}$ & $\mathrm{H}$ & $\mathrm{OH}$ & $\mathrm{OMe}$ & 5.0 & 17.1 & 3.1 \\
\hline $12 \mathrm{~g}$ & $\mathrm{~S}$ & $\mathrm{H}$ & $\mathrm{OMe}$ & $\mathrm{OH}$ & $\mathrm{H}$ & $\mathrm{OMe}$ & $\mathrm{H}$ & $\mathrm{OH}$ & $\mathrm{OMe}$ & 8.9 & n.a. & 7.6 \\
\hline $12 \mathrm{~h}$ & $S$ & $\mathrm{OMe}$ & $\mathrm{H}$ & $\mathrm{H}$ & $\mathrm{OMe}$ & $\mathrm{OH}$ & $\mathrm{H}$ & $\mathrm{OH}$ & $\mathrm{OH}$ & 13.7 & 8.4 & 10.5 \\
\hline $12 \mathrm{i}$ & $S$ & $\mathrm{H}$ & $\mathrm{OH}$ & $\mathrm{H}$ & $\mathrm{H}$ & $\mathrm{OH}$ & $\mathrm{H}$ & $\mathrm{OH}$ & $\mathrm{H}$ & n.a. & n.a. & 19.0 \\
\hline $12 \mathrm{j}$ & $S$ & $\mathrm{H}$ & $\mathrm{OH}$ & $\mathrm{H}$ & $\mathrm{H}$ & $\mathrm{OH}$ & $\mathrm{OMe}$ & $\mathrm{OMe}$ & $\mathrm{H}$ & 14.7 & n.a. & 15.7 \\
\hline $13 a$ & $\mathrm{D}$ & $\mathrm{H}$ & $\mathrm{OMe}$ & $\mathrm{OH}$ & $\mathrm{H}$ & -- & -- & -- & -- & 10.9 & 23.9 & 11.2 \\
\hline $13 b$ & $\mathrm{D}$ & $\mathrm{OMe}$ & $\mathrm{H}$ & $\mathrm{H}$ & $\mathrm{OMe}$ & -- & -- & -- & -- & 13.3 & n.a. & 19.9 \\
\hline $13 \mathrm{c}$ & D & \multicolumn{4}{|c|}{ 1-(2-thienyl) } & -- & -- & -- & -- & n.a. & n.a. & 26.3 \\
\hline $14 a$ & $\mathrm{D}$ & $\mathrm{H}$ & $\mathrm{OMe}$ & $\mathrm{OH}$ & $\mathrm{H}$ & $\mathrm{H}$ & $\mathrm{OMe}$ & $\mathrm{OH}$ & $\mathrm{H}$ & 7.1 & 8.1 & 7.5 \\
\hline $14 b$ & $\mathrm{D}$ & $\mathrm{H}$ & $\mathrm{H}$ & $\mathrm{OMe}$ & $\mathrm{H}$ & $\mathrm{H}$ & $\mathrm{H}$ & $\mathrm{OMe}$ & $\mathrm{H}$ & n.a. & 9.7 & 9.9 \\
\hline $14 c$ & D & $\mathrm{H}$ & $\mathrm{H}$ & $\mathrm{OH}$ & $\mathrm{H}$ & $\mathrm{H}$ & $\mathrm{H}$ & $\mathrm{OH}$ & $\mathrm{H}$ & 3.5 & 9.8 & 4.1 \\
\hline 14d & $\mathrm{D}$ & $\mathrm{H}$ & $\mathrm{OH}$ & $\mathrm{H}$ & $\mathrm{H}$ & $\mathrm{H}$ & $\mathrm{OH}$ & $\mathrm{H}$ & $\mathrm{H}$ & 6.3 & 18.4 & 7.2 \\
\hline $14 \mathrm{e}$ & $\mathrm{D}$ & $\mathrm{H}$ & $\mathrm{NO}_{2}$ & $\mathrm{H}$ & $\mathrm{H}$ & $\mathrm{H}$ & $\mathrm{NO}_{2}$ & $\mathrm{H}$ & $\mathrm{H}$ & n.a. & 8.9 & 18.3 \\
\hline $14 f$ & D & \multicolumn{8}{|c|}{ 1,2-bis(2-thienyl) } & 20.4 & n.a. & 19.7 \\
\hline $14 \mathrm{~g}$ & $\mathrm{D}$ & $\mathrm{H}$ & $\mathrm{OMe}$ & $\mathrm{OH}$ & $\mathrm{H}$ & $\mathrm{H}$ & $\mathrm{H}$ & $\mathrm{OH}$ & $\mathrm{H}$ & 9.8 & 10.1 & 15.0 \\
\hline $14 \mathrm{~h}$ & $\mathrm{D}$ & $\mathrm{H}$ & $\mathrm{OMe}$ & $\mathrm{OH}$ & $\mathrm{H}$ & $\mathrm{OH}$ & $\mathrm{H}$ & $\mathrm{OH}$ & $\mathrm{OMe}$ & 0.45 & 7.9 & 0.71 \\
\hline $14 i$ & $\mathrm{D}$ & OMe & $\mathrm{H}$ & $\mathrm{H}$ & OMe & $\mathrm{OH}$ & $\mathrm{H}$ & $\mathrm{OH}$ & $\mathrm{OH}$ & 4.7 & 7.1 & 3.2 \\
\hline $14 \mathrm{j}$ & $\mathrm{D}$ & $\mathrm{H}$ & $\mathrm{OH}$ & $\mathrm{H}$ & $\mathrm{H}$ & $\mathrm{OH}$ & $\mathrm{H}$ & $\mathrm{OH}$ & $\mathrm{H}$ & 20.8 & n.a. & 10.6 \\
\hline
\end{tabular}

a: Bond $\mathrm{C}^{5}-\mathrm{C}^{6} \mathrm{~S}=$ single and $\mathrm{D}=$ double; $\mathrm{b}$ : human lung carcinoma cells (A-549); c: human colon carcinoma cells (HT-29); d: human breast adenocarcinoma cells (MDA-MB-231) 
Structurally simplified analogs of Lam-D, in which the lactone ring was removed, and, in the case of derivatives $\mathbf{1 1}$ and 13, an additional aryl group was removed, all had lower activity than Lam-D. These data reveal that the complete structure is crucial for biological activity, despite being less soluble in biological media than simpler molecules. In a general overview, oxidized derivatives showed greater activity than the corresponding reduced analogs [34]. These data reveal that the complete structure is crucial for biological activity, despite being less soluble in biological media than simpler molecules. In a general overview, oxidized derivatives showed greater activity than the corresponding reduced analogs. This fact can probably be attributed to the greater hydrogen bonding capacity of these analogs-namely, with active sites, as has been described for Lam-D [37]. The donor effect of the methoxy-substituents may explain why 12c and 14b were quite active despite not being able to act as hydrogen bond donors. Compounds 14g, 14a, 14h and Lam-D have identical substituents on their scaffolds and at position 1 of their aryl rings. For these compounds, the greater the substitution of the aryl ring at position 2 of the scaffold, the lower the activity. The simplified analog 14a maintained 63\% of activity of Lam-D in HT29 cells, and $\mathbf{1 4 g}$, which has a hydroxy group at C4" (the same position as C-3 in Lam-D) was nearly as active. The open lactone compound $\mathbf{1 4 h}$ may undergo lactonization in physiological conditions. Therefore, $\mathbf{1 4 h}$ merits further study as a pharmacodynamic improvement on Lam-D, a validated lead compound.

\section{Topoisomerases, the initial biomolecular engines of cell growth}

Topoisomerases, nuclear enzymes than can change the topology of DNA [40, 41], are amongst the most promising targets for inhibiting cellular proliferation. DNA topoisomerases are crucial in cellular replication; hence, they are especially attractive targets for cancer therapy. Interaction of a drug with a DNA topoisomerase can produce a stable, cytotoxic complex that inhibits post-cleavage DNA religation processes [42]. Indeed, this mode of action has been reported as a novel mechanism for many anticancer drugs [41].

Inhibition of topoisomerase I by Lam-D has been extensively studied in the past few years. Cancer cells are more susceptible to the DNA damage incurred, and thus are more likely to die. Hence, drugs targeted at topoisomerase I are selective for malignant cells. Like integrases, topoisomerases also cleave and join DNA, but via different pathways. The cytotoxicity of Lam-D is at least partly closely related to its inhibition of topoisomerase I. Interestingly, Vanhuyse et al. [43] reported that camptothecin-resistant P388CPT5 murine leukemia cells have a low relative index of resistance to Lam-D. Therefore, topoisomerase I is a privileged intracellular target for Lam-D.

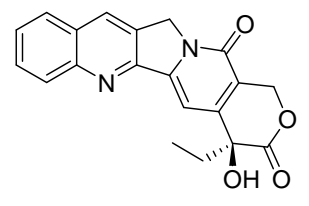

(S)-(+)-Camptothecin

Fig. (15). Structure of (+)-camptothecin 
P glycoprotein, the most common protein efflux pump in cells, also highly favours the activity of Lam-D in detrimental of recognized substrates like camptothecin. Investigations into the mechanism of action of Lam-D revealed that it is not sensitive to MDR-mediated drug efflux by $\mathrm{P}$ glycoprotein without active transporters to carry it out of the cell cytoplasm.

Although the pro-apoptotic effects of Lam-D could be understood as the final consequence of its stabilization of topoisomerase complexes, experiments [44] have revealed that it has other cellular targets. It has also been suggested that Lam-D induces apoptosis of leukemia cells by disrupting the mitochondrial transmembrane potential (MTP).

Using reliable real-time flow cytometry techniques and swelling of mitochondria isolated from leukemia cells, Bailly et al. showed that Lam-D directly induces MPT. Furthermore, they discovered that mitochondria are required to mediate Lam-D-induced nuclear apoptosis in a cell-free system [44].

In summary, Lam-D is rich in pharmacological potential which should be exploited for the development of treatments against chemoresistant cancer cells.

\section{Docking of LAM-D with topoisomerase I}

Computational techniques have been used to elucidate the structural basis and the mode of interaction of the covalent complex formed by Lam-D, topoisomerase I and DNA [37, 38]. Staker et al. [45] published a $2.10 \AA$ resolution crystal structure of human topoisomerase I covalently linked to double-stranded DNA (Protein Data Bank entry $1 \mathrm{k} 4 \mathrm{t}$ ) and the chemotherapy drug topotecan. It was used to model the Lam-Dmediated stabilization of topoisomerase I-DNA complex.

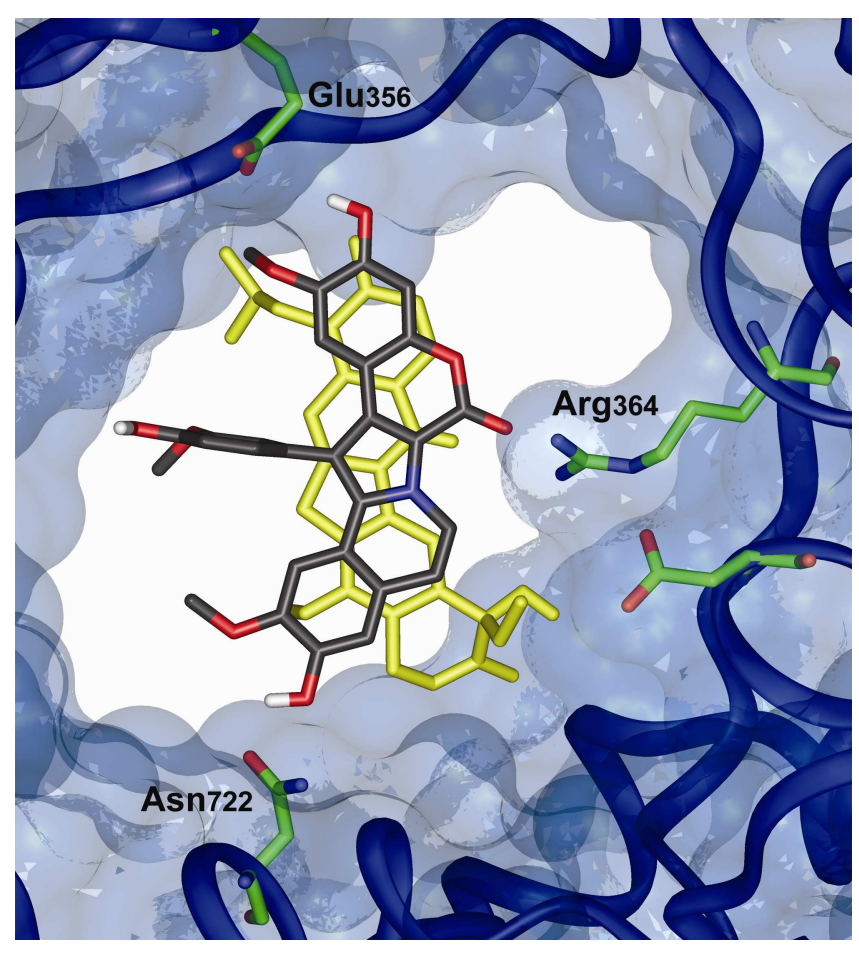


Fig. (16). Crystallographic model of topotecan-DNA-topoisomerase (Protein Data Bank entry 1k4t) featuring Lam-D superimposed in the active site [35]

Bailly et al. removed topotecan from the original structure to obtain a template on which to model the drugfree covalent complexes. The main difference between the two approaches [37, 38] remains in the exocyclic phenyl ring of Lam-D, which is rotated $180^{\circ}$ relative to the conformation reported in a previous very similar proposal, such that the methoxy group at $\mathrm{C} 13$ is close to the 6-amino group of adenosine in the major groove.

Finally, to support the latter refined [37] model of the cleavable Top1-DNA complex stabilized by Lam-D, a quantitative estimation of the contribution to the free energy of binding of the crucial 20-OH group was obtained through a set of precise, thermodynamic-integration free-energy simulations.

The inhibition of topoisomerase functionality alone probably does not result in cell death, but when the Lam-D stabilized ternary complex encounters a replication fork, the single DNA strand break is converted into a double DNA strand break which kills the cell.

\section{Lam-D: taking control of mitochondria}

Mitochondria [46, 47] are subcellular organelles evolved from bacterial symbiosis and therefore contain their own genome. Cancer cells have unlimited replicative potential; are resistant to cell death stimuli; exhibit several mitochondrial disorders (e.g. dysfunction, and genetic instability with alterations such as mutations, deletions or translocations of the mitochondrial DNA [mtDNA]); and are highly glycolytic. The rapid and continuous growth of tumor cells is highly energy-dependent, and cancer cells often develop drug resistance, consequently becoming unaffected by pro-apoptotic signals. The dependency of cancer cells on glycolysis for ATP synthesis indicates that the mitochondrial engineering of the respiratory chain might be inefficient. The significance of mitochondria in mediating apoptosis has led to an interest in exploiting radio- and chemo-therapeutic agents to trigger cancer cell death. To date, direct and specific targeting of mitochondria to obtain a persistent antitumor response has not been achieved, but there have been several encouraging cases in which some level of activity was reached. The vast majority of conventional anticancer drugs indirectly exploit mitochondria to exert cytotoxicity via multiple activation pathways that implicate $\mathrm{p} 53$ or death receptors.

mtDNA metabolism can also be targeted by topoisomerase inhibitors. Type I and type II topoisomerases have been identified in mitochondria, and have been shown to be inhibited there by known topoisomerase inhibitors.

Lam-D induces early disruption of the inner MPT through induction of pore opening [44]. This is considered as a predominant mechanism for mediating the release of pro-apoptotic molecules such as cytochrome $\mathrm{c}$ to the cytoplasm. Hence, agents that permeabilize cancer cell mitochondria may eliminate the resistance of these cells to apoptosis. Early studies have revealed that MPT pore opening precedes the proteolytic activation of caspase-3 in Lam-D mediated apoptosis. Furthermore, a greater gain in cell 
depolarization was observed in tumor cells (P388 leukemia, A549 lung cancer and MCF-7 breast cancer) rather than in non-tumor ones (NIH3T3 fibroblasts and $\mathrm{H} 9 \mathrm{C} 2$ cardiomyocytes). The direct targeting of mitochondria by Lam-D is highly advantageous over classical anticancer drugs. Lam-D may be effective for treating cancers in which signal transducing systems are interrupted (e.g. those implying mutations of p53).

\section{Focus on HIV integrase}

Current HIV treatments comprise reverse transcriptase inhibition, which prevents single-stranded viral RNA genome form being translated into double stranded DNA, and protease inhibition, which blocks the production of mature infectious virions. Whereas drugs that target these two viral enzymes have been in use for more than ten years, inhibitors of the third HIV enzyme, integrase (IN), have yet to be developed. Integrase is a viral protein of $32 \mathrm{kDa}$ responsible for the insertion of newly reverse-transcribed doublestranded viral DNA into the host genome [48]. An IN inhibitor could offer improvements in selectivity, despite the fact that the enzyme is only briefly active in the replication cycle of the virus. Integration of viral DNA into host cell chromosomal DNA to form a provirus is an essential step in the viral life cycle. IN is an ideal target for drug design because it does not have any known cellular homologs in mammals, and therefore, the reactions that it catalyzes are unique. Moreover, IN is required for viral replication and mutations in key residues. During the past 15 years many IN inhibitors have been identified, some of which are highly selective against IN and block viral replication. IN inhibitors fall into two major classes: catechol-containing hydroxylated aromatics and diketoacid-containing aromatics.

The mechanisms by which small molecule inhibitors of recombinant HIV-1 IN act are unknown. Important structural motifs identified to date for HIV-integrase inhibitors are 1,2- and 1,4-diphenols, which can be oxidated to the corresponding quinones [49, 50].

Ridley et al. [50] reported that the sulfate group is critical for the anti-HIV-1 integrase activity of Lam- $\alpha$ 20 -sulfate, because Lam- $\alpha$ showed no inhibition of HIV-1 integrase at concentrations up to $1.6 \mu \mathrm{M}$. HIV-1 integrase has been demonstrated to be a DNA manipulating enzyme and is a rarely exploited target. The low cytotoxicity of the sulfate compounds is interesting in the context of antiviral agents. Indeed, during a screening program aimed at identifying inhibitors of HIV-1 integrase. Reddy et al. [9] discovered that Lam$\alpha$ 20-sulfate [25] strongly inhibited both terminal cleavage of integrase and strand transfer in vitro. However, they reported that the disulfate analog Lam- $\alpha$ 13,20-disulfate is less selective than Lam- $\alpha$ 20sulfate, as they observed it to inhibit molluscum contagiosum virus (MCV) topoisomerase at roughly the same concentration as that used in the HIV-1 integrase assay.

Lam-H—which has six OH groups, all ortho to each other-exhibited very potent inhibition of HIV-1 integrase $\left(\mathrm{IC}_{50}=1.3 \mu \mathrm{M}\right)$, but unfortunately, was even more active in the non-selective $\mathrm{MCV}$ topoisomerase counterscreen $\left(\mathrm{IC}_{50}=0.23 \mu \mathrm{M}\right)$. It was very cytotoxic toward HeLa cells $\left(\mathrm{LD}_{50}=5.7 \mu \mathrm{M}\right)$. 
Table 6. Inhibition of HIV-1 integrase and of MCV topoisomerase, and cytotoxicity, of several lamellarin sulfates $[9,50]$

\begin{tabular}{|c|c|c|c|}
\hline Compound & $\mathbf{I C}_{\mathbf{5 0}}$ Integrase $(\boldsymbol{\mu M})$ & $\mathbf{I C}_{\mathbf{5 0}} \mathbf{M C V}(\boldsymbol{\mu M})$ & $\mathbf{L D}_{\mathbf{5 0}}$ Cytotoxicity $(\boldsymbol{\mu M})$ \\
\hline Lam-H $^{\mathrm{a}}$ & 1.3 & 0.23 & 5.7 \\
\hline Lam-N $^{\mathrm{b}}$ & 19 & 100 & 5 \\
\hline Lam-T $^{\mathrm{b}}$ & 24 & 100 & 27 \\
\hline Lam-U 20-sulfate $^{\mathrm{b}}$ & 25 & 500 & 145 \\
\hline Lam-V 20-sulfate $^{\mathrm{b}}$ & 51 & 500 & 28 \\
\hline Lam-W & 170 & 5.1 \\
\hline Lam- $\alpha^{\text {a }}$ & 14 & ND & 274 \\
\hline Lam- $\alpha 20-$ sulfate $^{\mathrm{a}, \mathrm{b}}$ & 1600 & $\geq 170$ & 29 \\
\hline Lam- $\alpha 13,20-$ disulfate $^{\mathrm{a}}$ & 22 & 70 & 130 \\
\hline
\end{tabular}

Infection assays were performed using either (a) HeLa cells or (b) p4 - 2 cells.

This review clearly illustrates the importance of natural products in drug discovery as well as in the development of new synthetic methods. Since first being isolated from natural sources, lamellarins have been extensively screened against numerous therapeutic targets and have inspired novel synthetic strategies for natural targets and related analogs.

Acknowledgements. The work carried out in the laboratory of the authors was partially supported by CICYT (CTQ2006-03794/BQU), Instituto de Salud Carlos III (CB06-01-0074), the Generalitat de Catalunya (2005SGR 00662), the Institute for Research in Biomedicine, and the Barcelona Science Park.

\author{
Abbreviations \\ A549 human lung cancer cells \\ CEM human leukemic lymphoid cells \\ $\mathrm{CEM} / \mathrm{C} 2$ human leukemia cells resistant to camptothecin \\ COLO205 colon cancer cells \\ DCE dichloroethane \\ DDQ 2,3-dichloro-5,6-dicyanoquinone \\ DIEA diisopropylethylamine \\ DMF dimethylformamide \\ DMSO dimethylsulfoxide \\ DNA deoxyribonucleic acid \\ DOPA 3,4-dihydoxyphenylalanine
}


DTBMP 2,6-di-tert-butyl-4-methylpyridine

DU145 human prostate carcinoma cells

GI growing inhibition

H9C2 fetal rat heart cells

HeLa cervical cancer cells

HIV human immunodeficiency virus

HT 29 human colon cancer cells

IC Inhibitory concentration

IN integrase

Lam lamellarin

LD letal dose

$\mathrm{MCV}$ molluscum contagiosum virus

MCF-7 human breast adenocarcinoma cells

MDA-MB-231 human breast adenocarcinoma cancer cells

MDCK Madin-Darby canine kidney cells

MDR multidrug resistant or resistance

MR Merrifield resin

MTP mitochondria transmembrane potential

NIH3T3 mouse embryonic fibroblast cells

NBS $N$-bromosuccinimide

PVPHP polymer bound pyridine hydrobromide perbromide

SAR structure activity relationship

SPS solid-phase synthesis

Tf triflate

TFA trifluoroacetic acid

THF tetrahydrofurane

TIPS triisopropylsilyl

Top-1 topoisomerase 1

Ts tosyl

$\mathrm{XC}$ sarcoma virus transformed rat cell line

WR Wang resin

\section{References}

[1] R. J. Andersen, D. J. Faulkner, H. Cun-heng, G. D. Van Duyne, J. Clardy J. Am. Chem. Soc. 1985, 107, 5492-5495.

[2] R. A. Davis, A. R. Carroll, G. K. Pierens, R. J. Quinn J. Nat. Prod. 1999, 62, 419-424.

[3] N. Lindquist, W. Fenical, G. D. Van Duyne, J. Clardy J. Org. Chem. 1988, 19, 4570-4574.

[4] A. R. Carroll, B. F. Bowden, J. C. Coll Aust. J. Chem. 1993, 46, 489-501.

[5] M. V. R. Reddy, D. J. Faulkner, Y. Venkateswarlu, M. R. Rao Tetrahedron 1997, 53, 3457-3466. 
[6] J. Ham, H. Kang Bull. Korean Chem. Soc. 2002, 23, 163-166.

[7] P. Krishnaiah, V. L. N. Reddy, G. Venkataramana, K. Ravinder, M. Srinivasulu, T. V. Raju, K. Ravikumar, D. Chandrasekar, S. Ramakrishna, Y. Venkateswarlu J. Nat. Prod. 2004, 67, 1168-1171.

[8] S. M. Reddy, M. Srinivasulu, N. Satyanarayana, A. K. Kondapib, Y. Venkateswarlu Tetrahedron 2005, 61, 9242-9247.

[9] R. M. V. Reddy, M. R. Rao, D. Rhodes, M. S. T. Hansen, K. Rubins, F. D. Bushman, Y. Venkateswarlu, D. V. Faulkner, J. Med. Chem. 1999, 42, 1901-1907.

[10] S. Urban, M. S. Butlet, R. J. Capon Aust. J. Chem. 1994, 47, 1919-1924.

[11] S. Urban, L. Hobbs, J. N. A. Hooper, R. J. Capon Aust. J. Chem. 1995, 48, 1491-1494.

[12] W. Y. Yoshida, K. K. Lee, A. R. Carroll, P. J. Scheuer Helv. Chim. Acta 1992, 75, 1721-1725.

[13] H. Kang, W. Fenical J. Org. Chem. 1997, 62, 3254-3262.

[14] A. Rudi; D. I Goldberg; Z. S. F. Frolow; Y. Benayahu; M. Schleyer and Y. Kashman J. Org. Chem. 1994, 59, 999-1003.

[15] G. W. Chan, T. Francis, D. R. Thureen, P. H. Offen, N. J. Pierce, J. W. Westley, R. K. Johnson J. Org. Chem. 1993, 58, 2544-2546.

[16] Recent revisions about lamellarin alkaloids: a) Bailly, C. Curr. Med. Chem.: Anti-Cancer Agents 2004, 4, 363. b) P. Cironi, F. Albericio, M. Álvarez Progress in Heterocyclic Chemistry, Gribble, G. W., Joule, J. A., Eds.; Pergamon: Oxford, U.K., 2004; Vol. 16, pp 1-26; c) S. T. Handy, Y. Zhang Org. Prep. Proc. 2005, 37, 411-445.

[17] P. Ploypradith, C. Mahidol, P. Sahakitpichan, S. Wongbundit, S. Ruchirawat Angew. Chem. Int. Ed. 2004, 43, 866-868.

[18] P. Ploypradith, T. Petchmanee, P. Sahakitpichan, N. D. Litvinas, S. Ruchirawat J. Org. Chem. 2006, 71, 9440-9448.

[19] P. Ploypradith, R. K. Kagan, S. Ruchirawat J. Org. Chem. 2005, 70, 5119-5125.

[20] P. Cironi, C. Cuevas, F. Albericio, M. Álvarez Tetrahedron 2004, 60, 8669-8675.

[21] P. Cironi, I. Manzanares, F. Albericio, M. Álvarez Org. Lett. 2003, 5, 2959-2962.

[22] C. Peschko, C. Winklhofer, A. Terpin, W. Steglich Synthesis 2006, 3048-3057.

[23] P. Mathew, C. V. Asokan Tetrahedron Lett. 2005, 46, 475-478.

[24] A. Fürstner, H. Weintritt, A. Hupperts J. Org. Chem.1995, 60, 6637-7741.

[25] Non systematic IUPAC numeration

[26] T. Yamaguchi, T. Fukuda, F. Ishibashi, M. Iwao Tetrahedron Lett. 2006, 47, 3755-3757.

[27] N. Fujikawa, T. Ohta, T. Yamaguchi, T. Fukuda, F. Ishibashib, M. Iwao Tetrahedron 2006, 62, 594604.

[28] M. Nyerges, L. Töke Tetrahedron Lett. 2005, 46, 7531-7534.

[29] S. Su, J. A. Porco, Jr. J . Am. Chem. Soc. 2007, 129, 7744-7745.

[30] M. Marfil, F. Albericio, M. Álvarez Tetrahedron 2004, 60, 8659-8668.

[31] S. T. Handy, Y. Zhang, H. Bregmn J. Org. Chem. 2004, 69, 2362-2366.

[32] C. Olsen, N. Parera, F. Albericio, M. Álvarez Tetrahedron Lett. 2005, 46, 2041-2044.

[33] D. Pla, A. Marchal, C. Olsen, F. Albericio, M. Álvarez J. Org. Chem. 2005, 70, 8231-8234.

[34] D. Pla, A. Marchal, C. A. Olsen, A. Francesch, C. Cuevas, F. Albericio, M. Alvarez J. Med. Chem. 2006, 49, 3257-3268.

[35] M. G. Banwell, E. Hamel, D. C. R. Hockless, P. Verdier-Pinard, A. C. Willis, D. J. Wong Bioorg. Med. Chem. 2006, 14, 4627-4638.

[36] J. A. Smith, S. Ng, J. White Org. Biomol. Chem. 2006, 4, 2477-2482.

[37] E. Marco, W. Laine, C. Tardy, A. Lansiaux, M. Iwao, F. Ishibashi, C. Bailly, F. Gago J. Med. Chem.

2005, 48, 3796-3807.

[38] M. Facompré, C. Tardy, C. Bal-Mayeu, P. Colson, C. Pérez, I. Manzanares; C. Cuevas; C. Bailly Cancer Res. 2003, 63, 7392-7399.

[39] F. Ishibashi, S. Tanabe, T. Oda, M. Iwao J. Nat. Prod. 2002, 65, 500-504.

[40] a) F. Cortés, N. Pastor, S. Mateos, I. Domínguez Expert Opin. Ther. Patents 2007, 17, 1-12. b) K. D. Corbett, J. M. Berger Annu. Rev. Biophys. Biomol. Struct. 2004, 33, 95-118.

[41] J. A. Holden Curr. Med. Chem. - Anti-Cancer Agents 2001, 1, 1-25.

[42] N. Dias, H. Vezin, A. Lansiaux, C. Bailly Top. Curr. Chem. 2005, 253, 89-108.

[43] M. Vanhuyse, J. Kluza, C. Tardy, G. Otero, C. Cuevas, C. Bailly, A. Lansiaux Cancer Lett. 2005, 221, $165-175$. 
[44] J. Kluza, M.A. Gallego, A. Loyens, J. C. Beauvillain, J. M. Fernandez Sousa-Faro, C. Cuevas, P. Marchetti, C. Bailly Cancer Res. 2006, 66, 3177-3187.

[45] B. L. Staker, K. Hjerrild, M. D. Feese, C. A. Behnke, A. B. Burgin, L.

Stewart Proc. Natl. Acad. Sci. USA 2002, 99, 15387-15392.

[46] J. A. Dykens, L. D. Marroquin, Y. Will Expert Rev. Mol. Diagn. 2007, 7, 161-175.

[47] N. Dias, C. Bailly Biochem. Pharm. 2005, 70, 1-12.

[48] D. C. Meadows, J. Gervay-Hague Chem. Med. Chem. 2006, 1, 16-29.

[49] J. Y. Lee, K. J. Yoon, Y. S. Lee Bioorg. Med. Chem. Lett. 2003, 13, 4331-4334.

[50] C. P. Ridley, M. V. R. Reddy, G. Rocha, F. D. Bushman, D. J. Faulkner Bioorg. Med. Chem. 2002, 10, 3285-3290. 
Table 1. Structure of reduced pentacyclic lamellarins

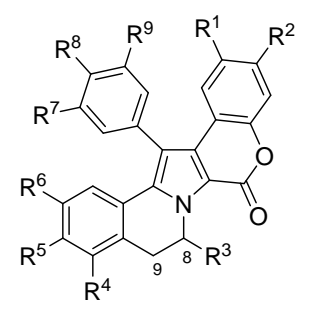

\begin{tabular}{|c|c|c|c|c|c|c|c|c|c|c|}
\hline Lamellarins & $\mathrm{R}^{1}$ & $\mathrm{R}^{2}$ & $\mathrm{R}^{3}$ & $\mathrm{R}^{4}$ & $\mathrm{R}^{5}$ & $\mathrm{R}^{6}$ & $\mathrm{R}^{7}$ & $\mathrm{R}^{8}$ & $\mathrm{R}^{9}$ & Ref \\
\hline Lam-A & $\mathrm{OMe}$ & $\mathrm{OH}$ & $\mathrm{OH}$ & $\mathrm{OMe}$ & $\mathrm{OMe}$ & $\mathrm{OMe}$ & $\mathrm{OMe}$ & $\mathrm{OH}$ & $\mathrm{H}$ & [1] \\
\hline Lam-C & $\mathrm{OMe}$ & $\mathrm{OH}$ & $\mathrm{H}$ & $\mathrm{OMe}$ & $\mathrm{OMe}$ & $\mathrm{OMe}$ & $\mathrm{OMe}$ & $\mathrm{OH}$ & $\mathrm{H}$ & [1] \\
\hline Lam-C sulf. & $\mathrm{OMe}$ & $\mathrm{OSO}_{3} \mathrm{Na}$ & $\mathrm{H}$ & $\mathrm{OMe}$ & $\mathrm{OMe}$ & $\mathrm{OMe}$ & $\mathrm{OMe}$ & $\mathrm{OH}$ & $\mathrm{H}$ & [2] \\
\hline Lam-E & $\mathrm{OMe}$ & $\mathrm{OH}$ & $\mathrm{H}$ & $\mathrm{OH}$ & $\mathrm{OMe}$ & $\mathrm{OMe}$ & $\mathrm{OH}$ & $\mathrm{OMe}$ & $\mathrm{H}$ & [3] \\
\hline Lam-F & $\mathrm{OMe}$ & $\mathrm{OH}$ & $\mathrm{H}$ & $\mathrm{OH}$ & $\mathrm{OMe}$ & $\mathrm{OMe}$ & $\mathrm{OMe}$ & $\mathrm{OMe}$ & $\mathrm{H}$ & [3] \\
\hline Lam-G & $\mathrm{OH}$ & $\mathrm{OMe}$ & $\mathrm{H}$ & $\mathrm{H}$ & $\mathrm{OH}$ & $\mathrm{OMe}$ & $\mathrm{OH}$ & $\mathrm{OMe}$ & $\mathrm{H}$ & [3] \\
\hline Lam-G sulf. & $\mathrm{OH}$ & $\mathrm{OMe}$ & $\mathrm{H}$ & $\mathrm{OSO}_{3} \mathrm{Na}$ & $\mathrm{OH}$ & $\mathrm{OMe}$ & $\mathrm{OH}$ & $\mathrm{OMe}$ & $\mathrm{H}$ & [2] \\
\hline Lam-I & $\mathrm{OMe}$ & $\mathrm{OH}$ & $\mathrm{H}$ & $\mathrm{OMe}$ & $\mathrm{OMe}$ & $\mathrm{OMe}$ & $\mathrm{OMe}$ & $\mathrm{OMe}$ & $\mathrm{H}$ & [4] \\
\hline Lam-J & $\mathrm{OMe}$ & $\mathrm{OH}$ & $\overline{\mathrm{H}}$ & $\mathrm{H}$ & $\mathrm{OH}$ & $\mathrm{OMe}$ & $\mathrm{OMe}$ & $\mathrm{OMe}$ & $\mathrm{H}$ & [4] \\
\hline Lam-K & $\mathrm{OMe}$ & $\mathrm{OH}$ & $\overline{\mathrm{H}}$ & $\mathrm{OH}$ & $\mathrm{OMe}$ & $\mathrm{OMe}$ & $\mathrm{OMe}$ & $\mathrm{OH}$ & $\mathrm{H}$ & [4] \\
\hline Lam-L & $\mathrm{OMe}$ & $\mathrm{OH}$ & $\mathrm{H}$ & $\mathrm{H}$ & $\mathrm{OH}$ & $\mathrm{OMe}$ & $\mathrm{OH}$ & $\mathrm{OMe}$ & $\mathrm{H}$ & [4] \\
\hline L sulf. & $\mathrm{OMe}$ & $\mathrm{OSO}_{3} \mathrm{Na}$ & $\mathrm{H}$ & $\mathrm{H}$ & $\mathrm{OH}$ & $\mathrm{OMe}$ & $\mathrm{OH}$ & $\mathrm{OMe}$ & $\mathrm{H}$ & [2] \\
\hline Lam-S & $\mathrm{OH}$ & $\mathrm{OH}$ & $\mathrm{H}$ & $\mathrm{H}$ & $\mathrm{OH}$ & $\mathrm{OMe}$ & $\mathrm{OH}$ & $\mathrm{OH}$ & $\mathrm{H}$ & [2] \\
\hline Lam-T & $\mathrm{OMe}$ & $\mathrm{OH}$ & $\mathrm{H}$ & $\mathrm{OMe}$ & $\mathrm{OMe}$ & $\mathrm{OMe}$ & $\mathrm{OH}$ & $\mathrm{OMe}$ & $\mathrm{H}$ & [5] \\
\hline Lam-T sulf. & $\mathrm{OMe}$ & $\mathrm{OSO}_{3} \mathrm{Na}$ & $\mathrm{H}$ & $\mathrm{OMe}$ & $\mathrm{OMe}$ & $\mathrm{OMe}$ & $\mathrm{OMe}$ & $\mathrm{OH}$ & $\mathrm{H}$ & [5] \\
\hline Lam-U & $\mathrm{OMe}$ & $\mathrm{OH}$ & $\mathrm{H}$ & $\mathrm{H}$ & $\mathrm{OMe}$ & $\mathrm{OMe}$ & $\mathrm{OH}$ & $\mathrm{OMe}$ & $\overline{\mathrm{H}}$ & [2] \\
\hline Lam-U sulf. & $\mathrm{OMe}$ & $\mathrm{OSO}_{3} \mathrm{Na}$ & $\mathrm{H}$ & $\mathrm{H}$ & $\mathrm{OMe}$ & $\mathrm{OMe}$ & $\mathrm{OH}$ & $\mathrm{OMe}$ & $\mathrm{H}$ & [5] \\
\hline Lam-V & $\mathrm{OMe}$ & $\mathrm{OH}$ & $\overline{\mathrm{OH}}$ & $\mathrm{OMe}$ & $\mathrm{OMe}$ & $\mathrm{OMe}$ & $\mathrm{OH}$ & $\mathrm{OMe}$ & $\mathrm{H}$ & [5] \\
\hline Lam-V sulf. & $\mathrm{OMe}$ & $\mathrm{OSO}_{3} \mathrm{Na}$ & $\overline{\mathrm{OH}}$ & $\mathrm{OMe}$ & $\mathrm{OMe}$ & $\mathrm{OMe}$ & $\mathrm{OH}$ & $\mathrm{OMe}$ & $\mathrm{H}$ & [5] \\
\hline Lam-Y & $\mathrm{OMe}$ & $\mathrm{OH}$ & $\mathrm{H}$ & $\mathrm{H}$ & $\mathrm{OMe}$ & $\mathrm{OH}$ & $\mathrm{OH}$ & $\mathrm{OMe}$ & $\mathrm{H}$ & [2] \\
\hline Lam-Y sulf. & $\mathrm{OMe}$ & $\mathrm{OSO}_{3} \mathrm{Na}$ & $\mathrm{H}$ & $\mathrm{H}$ & $\mathrm{OMe}$ & $\mathrm{OH}$ & $\mathrm{OH}$ & $\mathrm{OMe}$ & $\mathrm{H}$ & [5] \\
\hline Lam-Z & $\mathrm{OH}$ & $\mathrm{OMe}$ & $\mathrm{H}$ & $\mathrm{H}$ & $\mathrm{OH}$ & $\mathrm{OMe}$ & $\mathrm{OH}$ & $\mathrm{OH}$ & $\mathrm{H}$ & [2] \\
\hline Lam- $\beta$ & $\mathrm{OMe}$ & $\mathrm{OH}$ & $\mathrm{H}$ & $\mathrm{H}$ & $\mathrm{OH}$ & $\mathrm{OH}$ & $\mathrm{OH}$ & $\mathrm{OMe}$ & $\mathrm{H}$ & [6] \\
\hline Lam- $\gamma$ & $\mathrm{OMe}$ & $\mathrm{OH}$ & $\mathrm{H}$ & $\mathrm{OH}$ & $\mathrm{OMe}$ & $\mathrm{OMe}$ & $\mathrm{OH}$ & $\mathrm{OMe}$ & $\mathrm{OMe}$ & [7] \\
\hline Lam- $\chi$ triacetate & $\mathrm{OMe}$ & OAc & $\mathrm{H}$ & $\mathrm{H}$ & OAc & $\mathrm{OMe}$ & $\mathrm{OMe}$ & OAc & $\mathrm{H}$ & [8] \\
\hline Dihydro- Lam- $\eta$ & $\mathrm{OMe}$ & $\mathrm{OH}$ & $\mathrm{H}$ & $\mathrm{H}$ & $\mathrm{OMe}$ & $\mathrm{OMe}$ & $\mathrm{OMe}$ & $\mathrm{OMe}$ & $\mathrm{H}$ & [8] \\
\hline
\end{tabular}


Table 2. Structure of oxidized pentacyclic lamellarins

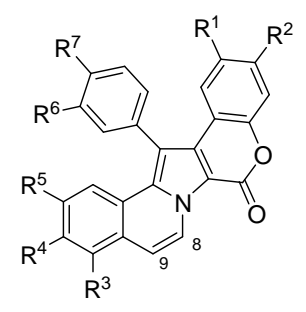

\begin{tabular}{|c|c|c|c|c|c|c|c|c|}
\hline Lamellarins & $\mathrm{R}^{1}$ & $\mathrm{R}^{2}$ & $\mathrm{R}^{3}$ & $\mathrm{R}^{4}$ & $\mathrm{R}^{5}$ & $\mathrm{R}^{6}$ & $\mathrm{R}^{7}$ & $\mathrm{Ref}$ \\
\hline Lam-B & $\mathrm{OMe}$ & $\mathrm{OH}$ & $\mathrm{OMe}$ & $\mathrm{OMe}$ & $\mathrm{OMe}$ & $\mathrm{OMe}$ & $\mathrm{OH}$ & {$[1]$} \\
\hline Lam-B sulf. & $\mathrm{OMe}$ & $\mathrm{OSO}_{3} \mathrm{Na}$ & $\mathrm{OMe}$ & $\mathrm{OMe}$ & $\mathrm{OMe}$ & $\mathrm{OMe}$ & $\mathrm{OH}$ & {$[2]$} \\
\hline Lam-D & $\mathrm{OMe}$ & $\mathrm{OH}$ & $\mathrm{H}$ & $\mathrm{OH}$ & $\mathrm{OMe}$ & $\mathrm{OMe}$ & $\mathrm{OH}$ & {$[1]$} \\
\hline Lam-H & $\mathrm{OH}$ & $\mathrm{OH}$ & $\mathrm{H}$ & $\mathrm{OH}$ & $\mathrm{OH}$ & $\mathrm{OH}$ & $\mathrm{OH}$ & {$[3]$} \\
\hline Lam-M & $\mathrm{OMe}$ & $\mathrm{OH}$ & $\mathrm{OH}$ & $\mathrm{OMe}$ & $\mathrm{OMe}$ & $\mathrm{OMe}$ & $\mathrm{OH}$ & {$[4]$} \\
\hline Lam-N & $\mathrm{OMe}$ & $\mathrm{OH}$ & $\mathrm{H}$ & $\mathrm{OH}$ & $\mathrm{OMe}$ & $\mathrm{OH}$ & $\mathrm{OMe}$ & {$[4]$} \\
\hline Lam-W & $\mathrm{OMe}$ & $\mathrm{OH}$ & $\mathrm{OMe}$ & $\mathrm{OMe}$ & $\mathrm{OMe}$ & $\mathrm{OH}$ & $\mathrm{OMe}$ & {$[5]$} \\
\hline Lam-X & $\mathrm{OMe}$ & $\mathrm{OH}$ & $\mathrm{OH}$ & $\mathrm{OMe}$ & $\mathrm{OMe}$ & $\mathrm{OH}$ & $\mathrm{OMe}$ & {$[2]$} \\
\hline Lam- $\alpha$ & $\mathrm{OMe}$ & $\mathrm{OH}$ & $\mathrm{H}$ & $\mathrm{OMe}$ & $\mathrm{OMe}$ & $\mathrm{OH}$ & $\mathrm{OMe}$ & {$[7]$} \\
\hline Lam- $\alpha$ sulf. & $\mathrm{OMe}$ & $\mathrm{OSO}{ }_{3} \mathrm{Na}$ & $\mathrm{H}$ & $\mathrm{OMe}$ & $\mathrm{OMe}$ & $\mathrm{OH}$ & $\mathrm{OMe}$ & {$[9]$} \\
\hline Lam- $\zeta$ & $\mathrm{OMe}$ & $\mathrm{OH}$ & $\mathrm{OMe}$ & $\mathrm{OMe}$ & $\mathrm{OMe}$ & $\mathrm{OMe}$ & $\mathrm{OMe}$ & {$[8]$} \\
\hline Lam- $\epsilon$ & $\mathrm{OMe}$ & $\mathrm{OH}$ & $\mathrm{OH}$ & $\mathrm{OMe}$ & $\mathrm{OMe}$ & $\mathrm{OMe}$ & $\mathrm{OMe}$ & {$[7]$} \\
\hline Lam- $\eta$ & $\mathrm{OMe}$ & $\mathrm{OH}$ & $\mathrm{H}$ & $\mathrm{OMe}$ & $\mathrm{OMe}$ & $\mathrm{OMe}$ & $\mathrm{OMe}$ & {$[8]$} \\
\hline Lam- $\phi$ & $\mathrm{OMe}$ & $\mathrm{OAc}$ & $\mathrm{OMe}$ & $\mathrm{OMe}$ & $\mathrm{OAc}$ & $\mathrm{OMe}$ & $\mathrm{OAc}$ & {$[8]$} \\
\hline
\end{tabular}


Table 3. Cytotoxicity of isolated lamellarins to various culture cell lines

\begin{tabular}{|c|c|c|c|}
\hline Isolated Compound & Culture Cell Line $^{a}$ & $\mathrm{IC}_{50}(\mathrm{M})^{\mathrm{b}}$ & Ref \\
\hline \multirow[t]{10}{*}{ Lam-D } & $\mathrm{HeLa}$ & $10.510^{-9}$ & [39] \\
\hline & CEM & $510^{-9}$ & \multirow[t]{2}{*}{ [37] } \\
\hline & CEM/C2 & $7.210^{-7}$ & \\
\hline & DU145 & $10.910^{-9 \mathrm{c}}$ & [8] \\
\hline & MDA-MB-231 & $2.510^{-7 \mathrm{c}}$ & \multirow{3}{*}{ [34] } \\
\hline & A549 & $210^{-7 c}$ & \\
\hline & HT29 & $5.110^{-6 \mathrm{c}}$ & \\
\hline & $\mathrm{XC}$ & $1.2410^{-8}$ & \multirow{3}{*}{ [39] } \\
\hline & Vero Cells & $1.0510^{-8}$ & \\
\hline & MDCK & $2.2510^{-8}$ & \\
\hline Lam-F & COLO205 & $910^{-9}$ & [8] \\
\hline Lam-H & $\mathrm{HeLa}$ & $>10^{-6}$ & [39] \\
\hline \multirow[t]{3}{*}{ Lam-H hexaacetate } & $\mathrm{HeLa}$ & $1.1510^{-5}$ & [39] \\
\hline & CEM & $1.9510^{-6}$ & \multirow{2}{*}{ [37] } \\
\hline & $\mathrm{CEM} / \mathrm{C} 2$ & $6.9310^{-6}$ & \\
\hline Lam-L triacetate & COLO205 & $0.2510^{-9}$ & [8] \\
\hline Lam-N & HeLa & $510^{-6}$ & [9] \\
\hline Lam-T & HeLa & $2.710^{-5 d}$ & [9] \\
\hline Lam-U sulf & HeLa & $1.410^{-4 \mathrm{~d}}$ & [9] \\
\hline Lam-V sulf & HeLa & $1.310^{-4 d}$ & [9] \\
\hline Lam-W & HeLa & $2.810^{-4 \mathrm{~d}}$ & [9] \\
\hline Lam- $\alpha$ & HeLa & $5.110^{-6 \mathrm{~d}}$ & [49] \\
\hline Lam- $\alpha$ sulf & $\mathrm{HeLa}$ & $2.7410^{-4 d}$ & [9] \\
\hline Lam- $\zeta$ & COLO205 & $5.610^{-9}$ & [8] \\
\hline Lam- $\chi$ & DU145 & $2.9910^{-6 c}$ & [8] \\
\hline Lam- $\chi$ triacetate & COLO205 & $0.210^{-9}$ & [8] \\
\hline \multirow[t]{4}{*}{ Lam- $\eta$} & HeLa & $2.510^{-6}$ & [39] \\
\hline & CEM & $3.0310^{-6}$ & \multirow{2}{*}{ [37] } \\
\hline & $\mathrm{CEM} / \mathrm{C} 2$ & $5.5510^{-6}$ & \\
\hline & COLO205 & $1.7810^{-7}$ & [8] \\
\hline Lam-dihydro $\eta$ & COLO205 & $510^{-8}$ & {$[8]$} \\
\hline Lam- $\phi$ & COLO205 & $5.610^{-8}$ & [8] \\
\hline
\end{tabular}

a: cervical cancer cells (HeLa); human leukemic lymphoid cells (CEM); human leukemia cells resistant to camptothecin (CEM/C2); human prostate carcinoma cells (DU145); Rous sarcoma virus transformed rat cell line (XC); monkey kidney epithelial cells (Vero cells); Madin-Darby canine kidney cells (MDCK); colon cancer cells (COLO205); human breast adenocarcinoma cancer cells (MDA-MB-231); human colon cancer cells (HT29); human lung cancer cells (A549); b: IC: inhibitory concentration (in most cases the values not comparable, because the assays were performed in different conditions); c: GI: growth inhibition; d) LD: lethal dose. 
Table 4. Cytotoxic activity of lamellarin derivatives 15a-I on HeLa Cells [39]

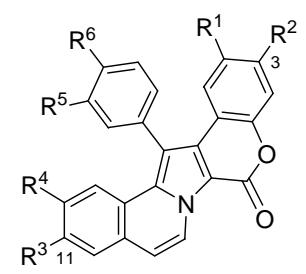

\begin{tabular}{|c|c|c|c|c|c|c|c|}
\hline Compound & $\mathbf{R}^{\mathbf{1}}$ & $\mathbf{R}^{\mathbf{2}}$ & $\mathbf{R}^{\mathbf{3}}$ & $\mathbf{R}^{\mathbf{4}}$ & $\mathbf{R}^{\mathbf{5}}$ & $\mathbf{R}^{\mathbf{6}}$ & $\mathbf{I C}_{\mathbf{5 0}}(\boldsymbol{\mu M})$ \\
\hline $\mathbf{1 5 a}$ & $\mathrm{OMe}$ & $\mathrm{OH}$ & $\mathrm{OH}$ & $\mathrm{OMe}$ & $\mathrm{OMe}$ & $\mathrm{OH}$ & $10.510^{-3}$ \\
\hline $\mathbf{1 5 b}$ & $\mathrm{OH}$ & $\mathrm{OH}$ & $\mathrm{OH}$ & $\mathrm{OH}$ & $\mathrm{OH}$ & $\mathrm{OH}$ & $>100$ \\
\hline $\mathbf{1 5 c}$ & $\mathrm{H}$ & $\mathrm{OH}$ & $\mathrm{OH}$ & $\mathrm{OMe}$ & $\mathrm{OMe}$ & $\mathrm{OH}$ & $39.510^{-3}$ \\
\hline $\mathbf{1 5 d}$ & $\mathrm{OMe}$ & $\mathrm{H}$ & $\mathrm{OH}$ & $\mathrm{OMe}$ & $\mathrm{OMe}$ & $\mathrm{OH}$ & 0.85 \\
\hline $\mathbf{1 5} \mathbf{e}$ & $\mathrm{OMe}$ & $\mathrm{OH}$ & $\mathrm{OMe}$ & $\mathrm{OMe}$ & $\mathrm{OMe}$ & $\mathrm{OMe}$ & 2.5 \\
\hline $\mathbf{1 5 f}$ & $\mathrm{OMe}$ & $\mathrm{OH}$ & $\mathrm{OH}$ & $\mathrm{OMe}$ & $\mathrm{H}$ & $\mathrm{OH}$ & $38.010^{-3}$ \\
\hline $\mathbf{1 5 g}$ & $\mathrm{OMe}$ & $\mathrm{OH}$ & $\mathrm{OH}$ & $\mathrm{OMe}$ & $\mathrm{OMe}$ & $\mathrm{H}$ & $70.010^{-3}$ \\
\hline $\mathbf{1 5 h}$ & $\mathrm{H}$ & $\mathrm{H}$ & $\mathrm{OH}$ & $\mathrm{OMe}$ & $\mathrm{OMe}$ & $\mathrm{OH}$ & 4.0 \\
\hline $\mathbf{1 5 i}$ & $\mathrm{H}$ & $\mathrm{H}$ & $\mathrm{OH}$ & $\mathrm{OH}$ & $\mathrm{OH}$ & $\mathrm{OH}$ & 1.1 \\
\hline $\mathbf{1 5 j}$ & $\mathrm{OAc}$ & $\mathrm{OAc}$ & $\mathrm{OAc}$ & $\mathrm{OAc}$ & $\mathrm{OAc}$ & $\mathrm{OAc}$ & 11.0 \\
\hline $\mathbf{1 5} \mathbf{n}$ & $\mathrm{H}$ & $\mathrm{H}$ & $\mathrm{OMe}$ & $\mathrm{OMe}$ & $\mathrm{OMe}$ & $\mathrm{OMe}$ & 5.7 \\
\hline $\mathbf{1 5 l}$ & \multicolumn{2}{|c|}{$-\mathrm{OCH}_{2} \mathrm{O}-$} & $\mathrm{OMe}$ & $\mathrm{OMe}$ & $\mathrm{OMe}$ & $\mathrm{OMe}$ & $>100$ \\
\hline
\end{tabular}


Table 5. Cytotoxicity $\left(\mathrm{GI}_{50} \mu \mathrm{M}\right)$ of open-lactone lamellarin analogs to various cancer cell lines [34]
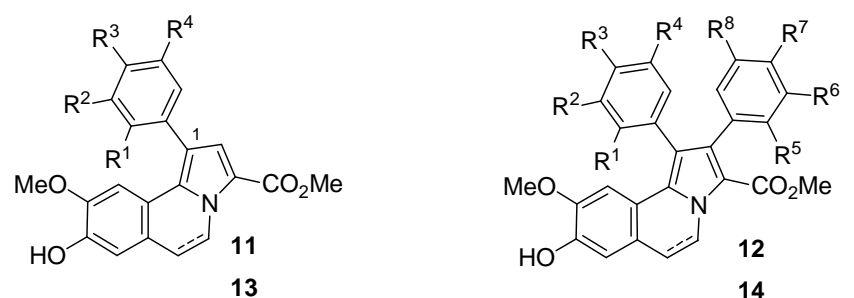

\begin{tabular}{|c|c|c|c|c|c|c|c|c|c|c|c|c|}
\hline Cmpd. & $\mathbf{B d}^{\mathrm{a}}$ & $\mathbf{R}^{1}$ & $\mathbf{R}^{2}$ & $\mathbf{R}^{3}$ & $\mathbf{R}^{4}$ & $\mathbf{R}^{5}$ & $\mathbf{R}^{6}$ & $\mathbf{R}^{7}$ & $\mathbf{R}^{8}$ & $A-549^{b}$ & HT-29 & $\begin{array}{l}\text { MDA- } \\
\text { MB- } \\
\text { 231 }^{\text {d }} \\
\end{array}$ \\
\hline \multicolumn{10}{|c|}{ Lam-D } & 0.20 & 5.1 & 0.25 \\
\hline 11a & $S$ & $\mathrm{H}$ & $\mathrm{OMe}$ & $\mathrm{OH}$ & $\mathrm{H}$ & -- & -- & -- & -- & 14.2 & 18.0 & 22.3 \\
\hline $11 b$ & $\mathrm{~S}$ & $\mathrm{OMe}$ & $\mathrm{H}$ & $\mathrm{H}$ & $\mathrm{OMe}$ & -- & -- & -- & -- & n.a. & n.a. & 12.7 \\
\hline $12 a$ & $\mathrm{~S}$ & $\mathrm{H}$ & $\mathrm{OMe}$ & $\mathrm{OH}$ & $\mathrm{H}$ & $\mathrm{H}$ & $\mathrm{OMe}$ & $\mathrm{OH}$ & $\mathrm{H}$ & 14.3 & n.a. & 8.5 \\
\hline $12 \mathrm{~b}$ & $S$ & $\mathrm{H}$ & $\mathrm{OMe}$ & $\mathrm{OMe}$ & $\mathrm{H}$ & $\mathrm{H}$ & $\mathrm{OMe}$ & $\mathrm{OMe}$ & $\mathrm{H}$ & 11.2 & n.a. & 7.7 \\
\hline $12 \mathrm{c}$ & $\mathrm{S}$ & $\mathrm{H}$ & $\mathrm{H}$ & $\mathrm{OMe}$ & $\mathrm{H}$ & $\mathrm{H}$ & $\mathrm{H}$ & $\mathrm{OMe}$ & $\mathrm{H}$ & 9.2 & 10.3 & 14.4 \\
\hline 12d & $\mathrm{S}$ & $\mathrm{H}$ & $\mathrm{H}$ & $\mathrm{NMe}_{2}$ & $\mathrm{H}$ & $\mathrm{H}$ & $\mathrm{H}$ & $\mathrm{NMe}_{2}$ & $\mathrm{H}$ & n.a. & n.a. & 13.7 \\
\hline $12 \mathrm{e}$ & $\mathrm{S}$ & $\mathrm{H}$ & $\mathrm{NO}_{2}$ & $\mathrm{H}$ & $\mathrm{H}$ & $\mathrm{H}$ & $\mathrm{NO}_{2}$ & $\mathrm{H}$ & $\mathrm{H}$ & 18.0 & 11.3 & 10.1 \\
\hline $12 \mathrm{f}$ & $\mathrm{S}$ & $\mathrm{H}$ & $\mathrm{OMe}$ & $\mathrm{OH}$ & $\mathrm{H}$ & $\mathrm{OH}$ & $\mathrm{H}$ & $\mathrm{OH}$ & $\mathrm{OMe}$ & 5.0 & 17.1 & 3.1 \\
\hline $12 \mathrm{~g}$ & $\mathrm{~S}$ & $\mathrm{H}$ & $\mathrm{OMe}$ & $\mathrm{OH}$ & $\mathrm{H}$ & $\mathrm{OMe}$ & $\mathrm{H}$ & $\mathrm{OH}$ & $\mathrm{OMe}$ & 8.9 & n.a. & 7.6 \\
\hline $12 \mathrm{~h}$ & $\mathrm{~S}$ & $\mathrm{OMe}$ & $\mathrm{H}$ & $\mathrm{H}$ & $\mathrm{OMe}$ & $\mathrm{OH}$ & $\mathrm{H}$ & $\mathrm{OH}$ & $\mathrm{OH}$ & 13.7 & 8.4 & 10.5 \\
\hline $12 \mathrm{i}$ & $S$ & $\mathrm{H}$ & $\mathrm{OH}$ & $\mathrm{H}$ & $\mathrm{H}$ & $\mathrm{OH}$ & $\mathrm{H}$ & $\mathrm{OH}$ & $\mathrm{H}$ & n.a. & n.a. & 19.0 \\
\hline $12 \mathrm{j}$ & $\mathrm{S}$ & $\mathrm{H}$ & $\mathrm{OH}$ & $\mathrm{H}$ & $\mathrm{H}$ & $\mathrm{OH}$ & $\mathrm{OMe}$ & $\mathrm{OMe}$ & $\mathrm{H}$ & 14.7 & n.a. & 15.7 \\
\hline $13 a$ & $\mathrm{D}$ & $\mathrm{H}$ & $\mathrm{OMe}$ & $\mathrm{OH}$ & $\mathrm{H}$ & -- & -- & -- & -- & 10.9 & 23.9 & 11.2 \\
\hline $13 b$ & $\mathrm{D}$ & $\mathrm{OMe}$ & $\mathrm{H}$ & $\mathrm{H}$ & $\mathrm{OMe}$ & -- & -- & -- & -- & 13.3 & n.a. & 19.9 \\
\hline $13 c$ & D & \multicolumn{4}{|c|}{ 1-(2-thienyl) } & -- & -- & -- & -- & n.a. & n.a. & 26.3 \\
\hline $14 a$ & $\mathrm{D}$ & $\mathrm{H}$ & $\mathrm{OMe}$ & $\mathrm{OH}$ & $\mathrm{H}$ & $\mathrm{H}$ & $\mathrm{OMe}$ & $\mathrm{OH}$ & $\mathrm{H}$ & 7.1 & 8.1 & 7.5 \\
\hline $14 \mathrm{~b}$ & D & $\mathrm{H}$ & $\mathrm{H}$ & $\mathrm{OMe}$ & $\mathrm{H}$ & $\mathrm{H}$ & $\mathrm{H}$ & $\mathrm{OMe}$ & $\mathrm{H}$ & n.a. & 9.7 & 9.9 \\
\hline $14 c$ & D & $\mathrm{H}$ & $\mathrm{H}$ & $\mathrm{OH}$ & $\mathrm{H}$ & $\mathrm{H}$ & $\mathrm{H}$ & $\mathrm{OH}$ & $\mathrm{H}$ & 3.5 & 9.8 & 4.1 \\
\hline 14d & $\mathrm{D}$ & $\mathrm{H}$ & $\mathrm{OH}$ & $\overline{\mathrm{H}}$ & $\mathrm{H}$ & $\mathrm{H}$ & $\mathrm{OH}$ & $\mathrm{H}$ & $\mathrm{H}$ & 6.3 & 18.4 & 7.2 \\
\hline $14 \mathrm{e}$ & $\mathrm{D}$ & $\mathrm{H}$ & $\mathrm{NO}_{2}$ & $\mathrm{H}$ & $\mathrm{H}$ & $\mathrm{H}$ & $\mathrm{NO}_{2}$ & $\mathrm{H}$ & $\mathrm{H}$ & n.a. & 8.9 & 18.3 \\
\hline $14 f$ & $\mathrm{D}$ & \multicolumn{8}{|c|}{ 1,2-bis(2-thienyl) } & 20.4 & n.a. & 19.7 \\
\hline $14 \mathrm{~g}$ & $\mathrm{D}$ & $\mathrm{H}$ & $\mathrm{OMe}$ & $\mathrm{OH}$ & $\mathrm{H}$ & $\mathrm{H}$ & $\mathrm{H}$ & $\mathrm{OH}$ & $\mathrm{H}$ & 9.8 & 10.1 & 15.0 \\
\hline $14 \mathrm{~h}$ & D & $\mathrm{H}$ & $\mathrm{OMe}$ & $\mathrm{OH}$ & $\mathrm{H}$ & $\mathrm{OH}$ & $\mathrm{H}$ & $\mathrm{OH}$ & $\mathrm{OMe}$ & 0.45 & 7.9 & 0.71 \\
\hline $14 i$ & $\mathrm{D}$ & $\mathrm{OMe}$ & $\mathrm{H}$ & $\mathrm{H}$ & OMe & $\mathrm{OH}$ & $\mathrm{H}$ & $\mathrm{OH}$ & $\mathrm{OH}$ & 4.7 & 7.1 & 3.2 \\
\hline $14 j$ & $\mathrm{D}$ & $\mathrm{H}$ & $\mathrm{OH}$ & $\mathrm{H}$ & $\mathrm{H}$ & $\mathrm{OH}$ & $\mathrm{H}$ & $\mathrm{OH}$ & $\mathrm{H}$ & 20.8 & n.a. & 10.6 \\
\hline
\end{tabular}

a: Bond $\mathrm{C}^{5}-\mathrm{C}^{6} \mathrm{~S}=$ single and $\mathrm{D}=$ double; $\mathrm{b}$ : human lung carcinoma cells (A-549); c: human colon carcinoma cells (HT-29); d: human breast adenocarcinoma cells (MDA-MB-231) 
Table 6. Inhibition of HIV-1 integrase and of MCV topoisomerase, and cytotoxicity, of several lamellarin sulfates $[9,50]$

\begin{tabular}{|c|c|c|c|}
\hline Compound & IC $_{\mathbf{5 0}}$ Integrase $(\boldsymbol{\mu M})$ & $\mathbf{I C}_{\mathbf{5 0}} \mathbf{M C V}(\boldsymbol{\mu M})$ & LD $_{\mathbf{5 0}}$ Cytotoxicity $(\boldsymbol{\mu M})$ \\
\hline Lam-H $^{\mathrm{a}}$ & 1.3 & 0.23 & 5.7 \\
\hline Lam-N $^{\mathrm{b}}$ & 19 & 100 & 5 \\
\hline Lam-T $^{\mathrm{b}}$ & 24 & 100 & 27 \\
\hline Lam-U 20-sulfate $^{\mathrm{b}}$ & 25 & 500 & 145 \\
\hline Lam-V 20-sulfate $^{\mathrm{b}}$ & 51 & 500 & 28 \\
\hline Lam-W & 170 & 5.1 \\
\hline Lam- ${ }^{\text {a }}$ & 14 & $\mathrm{ND}$ & 274 \\
\hline Lam- $\alpha 20-$ sulfate $^{\mathrm{a}, \mathrm{b}}$ & $>1600$ & $\geq 170$ & 29 \\
\hline Lam- $\alpha 13,20-$ disulfate $^{\mathrm{a}}$ & 22 & 70 & 130 \\
\hline
\end{tabular}

Infection assays were performed using either (a) HeLa cells or (b) p4 - 2 cells. 